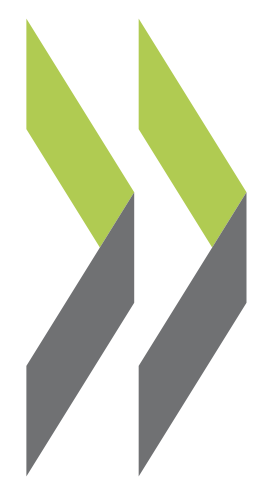

OECD Science, Technology and Industry Working Papers 2009/06

\title{
Trademarks as an Indicator of Product and Marketing Innovations
} Valentine Millot 
Organisation de Coopération et de Développement Économiques

Organisation for Economic Co-operation and Development

08-Apr-2009

DIRECTORATE FOR SCIENCE, TECHNOLOGY AND INDUSTRY

English - Or. English

TRADEMARKS AS AN INDICATOR OF PRODUCT AND MARKETING INNOVATIONS

STI WORKING PAPER 2009/6

Statistical Analysis of Science, Technology and Industry

Valentine Millot (OECD) 


\section{STI Working Paper Series}

The Working Paper series of the OECD Directorate for Science, Technology and Industry is designed to make available to a wider readership selected studies prepared by staff in the Directorate or by outside consultants working on OECD projects. The papers included in the series cover a broad range of issues, of both a technical and policy-analytical nature, in the areas of work of the DSTI. The Working Papers are generally available only in their original language - English or French - with a summary in the other.

Comments on the papers are invited, and should be sent to the Directorate for Science, Technology and Industry, OECD, 2 rue André-Pascal, 75775 Paris Cedex 16, France.

The opinions expressed in these papers are the sole responsibility of the author(s) and do not necessarily reflect those of the OECD or of the governments of its member countries.

\section{http://www.oecd.org/sti/working-papers}

OECD/OCDE, 2009

Applications for permission to reproduce or translate all or part of this material should be made to: OECD Publications, 2 rue André-Pascal, 75775 Paris, Cedex 16, France; e-mail: rights@oecd.org 
DSTI/DOC(2009)6

\title{
TRADEMARKS AS AN INDICATOR OF PRODUCT AND MARKETING INNOVATIONS
}

\author{
Valentine Millot (OECD)
}

\begin{abstract}
Non-technological innovation is a major factor of competitiveness and productivity growth in the economy, notably in the service industries. However, the measurement of non-technological innovation and of innovation in the service industries is currently very poor, as traditional data sources like R\&D or patents do not apply to these types of innovations. This document presents a strong candidate for quantifying non-technological innovation: trademark data.

Trademarks constitute a rich and easily accessible source of data. Besides, several studies have shown that they are highly correlated with various innovation variables (patents, share of innovative sales). Lastly, trademarks have a large perimeter of application; they are present in almost every sector of the economy. Trademark data are then likely to convey information on two key (overlapping) aspects of innovation that are not well covered by traditional indicators: innovation in the service sectors and marketing innovation.

This paper aims at presenting trademarks, their potential link with innovations and their main statistical properties, to see if they may actually serve as an innovation indicator.
\end{abstract}




\title{
LES MARQUES COMME INDICATEUR D'INNOVATIONS DE PRODUIT ET DE COMMERCIALISATION
}

\author{
Valentine Millot (OCDE)
}

\section{RÉSUMÉ}

L'innovation non technologique est un facteur majeur de croissance et de compétitivité, notamment dans les industries de services. Néanmoins, la mesure de l'innovation non technologique et de l'innovation dans les services est à l'heure actuelle très insuffisante, les indicateurs traditionnels tels que les dépenses de R\&D ou les brevets ne s'appliquant pas à ce type d'innovation. Ce document présente un candidat de poids pour quantifier l'innovation non-technologique: les données de marques.

Les marques constituent une source de données riche et facilement accessible. Par ailleurs, plusieurs études ont montré une forte corrélation entre les marques et différentes variables d'innovation (brevets, part de ventes liées à l'activité innovante). De plus, le périmètre d'application des marques est très étendu, elles sont présentes presque dans tous les secteurs de l'économie. Les marques sont ainsi susceptibles de fournir de l'information sur deux aspects importants de l'innovation (se superposant en partie) que les indicateurs traditionnels couvrent mal: les innovations dans les services et les innovations de commercialisation.

Ce document vise à présenter les marques, leur lien potentiel avec l'innovation et leurs principales propriétés statistiques, de manière à déterminer si elles peuvent effectivement servir d'indicateur d'innovation. 
TABLE OF CONTENTS

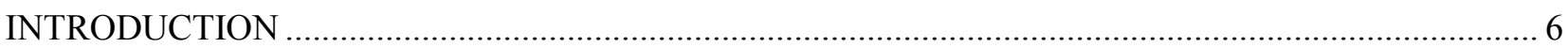

1. DEFINITION AND LEGAL ASPECTS OF TRADEMARKS …...................................................... 9

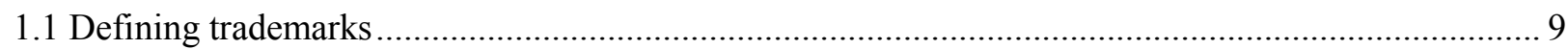

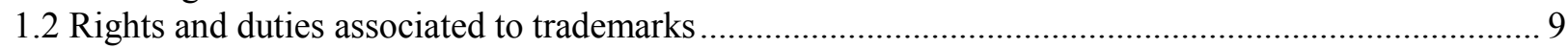

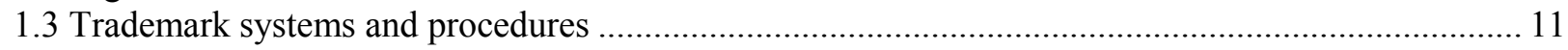

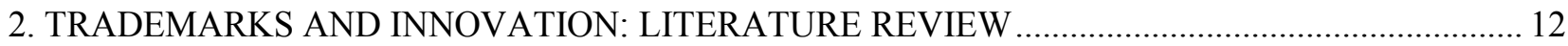

2.1 The use of branding in the launching of new products ..................................................................... 12

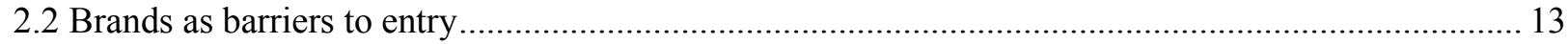

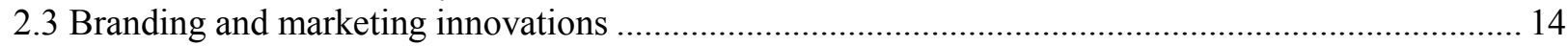

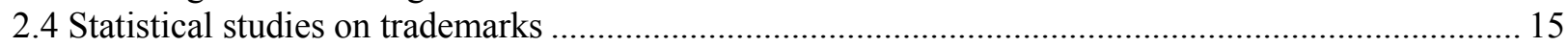

3. TRADEMARK DATA AS AN INNOVATION INDICATOR: PRELIMINARY STATISTICS AND

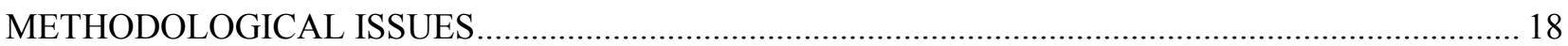

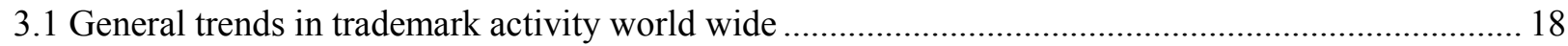

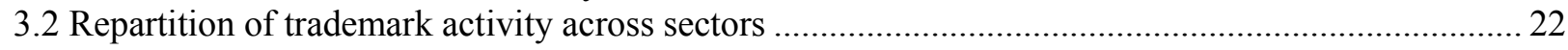

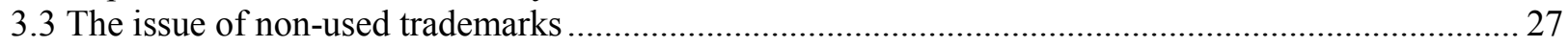

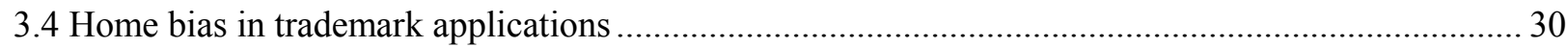

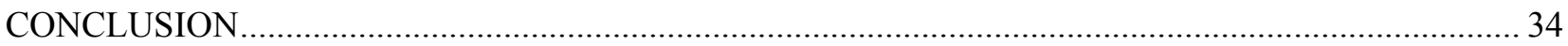

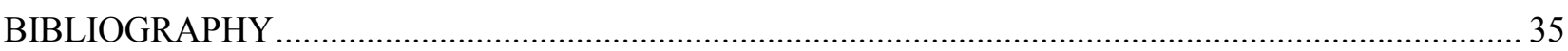

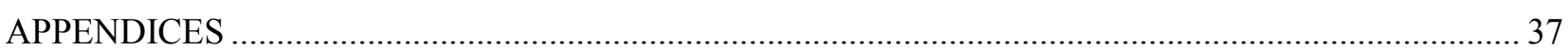




\section{INTRODUCTION}

As defined by law, a trademark is a sign (a word, a logo, a phrase, etc.) that enables people to distinguish the goods or services of one party from those of another. Trademarks constitute one of the most important assets of firms. It is mostly through them that people know the firms and that the firms' reputation can be built. They enable the consumers to differentiate between competitive offerings and possibly to develop loyalty towards one preferred trademark. This loyalty relationship enables the firm to charge higher prices and maintain higher margins ${ }^{1}$. Thus, trademarks play a key role in the activity of firms. According to R. Elliott and L. Percy [2006], a strong brand name is an essential factor in a company's financial success.

However, despite their great importance in economic life, trademarks have been relatively neglected in the economic literature (unlike in the business literature), and trademark data are not often used in economic analyses. It is yet assumable that they could provide some interesting information on various aspects of firms' activity. It can be notably expected that trademarks could bring information on innovative activity (Schmoch, 2003; Mendonça et al., 2004; Malmberg, 2005).

The only criterion to register a new trademark is the novelty of the sign itself, which must not be similar to any already registered trademark. The purpose is that the mark uniquely identifies a type of product, so as to prevent consumers' confusion. Contrary to patents, the registration of a trademark does not require the novelty of the product itself. At the legal level, the link between trademarks and innovation is consequently not straightforward.

In practice, however, trademarks are likely to be linked to the innovative activity of firms, at various levels. First, trademarks play a role in the commercialisation of new products. When they launch an innovation, firms may associate it to a new brand in order to help the perception of the innovation by consumers. The brand constitutes a basis on which firms advertise their product. Then the trademark has good chances to become a, or even the reference on the market for the product. Indeed the consumers who start buying one innovative product of one brand are likely to remain loyal to this brand. It is then difficult for competitors to enter the market. Thus trademarks can constitute a means to appropriate the benefits of an innovation. Various product innovations by firms are then associated to a trademark (e.g. the "Kleenex", invented in 1924 by the firm Kleenex; the "Walkman", first launched by Sony in 1979; the "i-phone", launched by Apple in 2007).

Besides, trademark deposits are likely to be related to marketing innovations, that is to say changes in marketing methods aiming at reaching new customers and improving sales. When firms want to reach new customers and change positioning on the market, it may be useful for them to create a new trademark. For example, we can mention the case of BMW, which already owns three trademarks (BMW, Mini and Rolls Royce), and which is currently considering starting up a new, exclusively green, brand, which would sell a line of ecologically friendly cars. Doing that, BMW launches a new marketing strategy, in order to reach

1. Brand loyalty leads indeed consumers to accept to pay a higher price for one product. According to Scott Davis (2002), $72 \%$ of customers in various market sectors would pay a $20 \%$ premium for their preferred brand; $50 \%$ would pay $30 \%$ more and $25 \%$ say that price does not matter. 
another target beyond its usual consumers. Interestingly enough, BMW considered that this line of products did not fit the marketing strategy of the existing brands, and that a new brand should consequently be created. "We cannot take the blue out of BMW and change it to green", said sales and marketing director Stefan Krause in an interview with trade journal Automotive News. "Maybe we could add a fourth brand." So in some cases, marketing innovations can lead to the registration of new trademarks. Furthermore, the creation of a new brand encourages in return making marketing innovations. Indeed, the aim of a trademark is to attract customers, and to build a loyalty relationship. For that, according to the marketing literature, the brand must differentiate from the others. This differentiation can be achieved through various marketing innovations, concerning for example the product packaging or the product promotion methods (Aaker, 1991; Kapferer, 1991; Elliott and Percy, 2006).

So, trademark data are susceptible to be related to innovation, both to product innovations, as they may play a role in the launching of new products on the market, and to marketing innovations, as they are closely related to the marketing strategies of firms. However, those intuitions do not constitute proof that there actually is a link between trademark deposits and innovations. This has to be verified empirically.

Several studies have shown through the analysis of empirical data that there is indeed a correlation between trademarks and innovative activity. First of all, the results of the CIS 4 indicate that innovative firms use more trademarks than non-innovative firms (see Appendix 2). We can also notice that the innovative firms use more trademarks than patents, especially in the service sector. This correlation between innovative activity and trademark deposits has been verified in various studies by academic researchers. Based on survey results at the firm level, they find a significant positive relation between trademark deposits and various innovation variables (patents, R\&D, share of turnover associated to new products, number of new products launched, etc.) in various sectors. They find a very significant correlation in the service sector and notably the knowledge-intensive services (Schmoch, 2003; Mendonça et al., 2004), in the high-tech sectors (Mendonça et al., 2004), and in other sectors, like the pharmaceutical industry, where the product targets consumers directly (Malmberg, 2005). We will come back on these studies more precisely in the second section of this paper.

The results showing a positive and significant correlation between trademarks and innovation in various sectors seem to suggest that trademarks could be used as an indicator for certain kinds of innovations, and complete the information brought by the other innovation indicators.

Trademark data present various practical advantages to be used as an indicator. They have been recorded regularly and systematically for decades in a large number of countries, at least in the leading economies. Moreover, they present all the practical characteristics required to constitute a good statistical indicator: there is a high number of trademark applications so it should be possible to achieve statistically relevant results, the data are accessible through electronic databases, they are disaggregated by classes of products, which should enable sectorial analyses, and they are present world wide, so international comparison is theoretically possible (Schmoch, 2003).

Furthermore, trademarks do not have the drawbacks generally associated with the traditional innovation indicators (patents and R\&D data).

One particular drawback of patents and R\&D is that they do not reflect the commercial aspect of innovations. Patents and R\&D data are more indicators of invention than indicators of innovation. Indeed, $R \& D$ is an input indicator, which does not reflect the technical success of innovations and even less their commercial success. As far as patents are concerned, many patented inventions are never commercialised, because they never give rise to concrete useful applications. Innovations refer precisely to those practical applications, which are prone to have a commercial value. Indeed, no matter the level of technological progress comprised in an invention, it will have no economic impact if it is not commercialised on the 
market. Contrary to patents and R\&D, trademarks are obviously linked to the commercialisation of products, as they are fundamentally used to sell products or services on the market. So they may bring another light on innovation, less focused on the technological side and more on the commercial aspect.

Besides, trademarks could make it possible to appraise some kinds of innovations that are not reflected by patents and R\&D data, especially the non-technological innovations, which have an increasing importance in service-intensive economies.

Non-technological innovations represent first the product innovations that take place in sectors with low technological content, notably the service sector. The Oslo Manual, since the second edition (1997), mentions that the analysis of innovation should include the service sector. Yet services stand mostly outside the area of patentable items and are generally not associated to any R\&D expenses. For this reason, service activities are nearly absent from traditional innovation studies (Cainelli et al., 2005). Frame and White (2002) notice, for example, a huge lack of empirical studies on financial innovation, though it constitutes "a bedrock" of financial systems. Contrary to patents and R\&D, the spectrum of trademarks is very large; they are present in almost every sector of the economy, including services. Trademarks are, what is more, especially important for services, as customers cannot try the service products before buying them and cannot make evidence-based choices. They need then to have particular guarantees that are likely to be provided by brands (Elliott and Percy, 2006). Thus trademarks could possibly mitigate the lack of information on innovation in the service sector.

Moreover, non-technological innovations are present beyond the service sector. Some kinds of nontechnological innovations play a role in every sector of the economy, including the manufacturing sector. They are defined in the third version of the Oslo Manual (2005). In this last version of the manual the word "technological" was retrieved from the definitions of innovation, and two new categories were added next to product and process innovations: organisational and marketing innovations. An organisational innovation is defined as "the implementation of a new organisational method in the firm's business practices, workplace organisation or external relations", and a marketing innovation is "the implementation of a new marketing method involving significant changes in product design or packaging, product placement, product promotion or pricing with the aim of reaching new customers and improving the sales." Those innovations are usually not patented, and they do not correspond to R\&D expenses either, as they generally stem from other departments of the firm, e.g. the marketing department. To appraise those kinds of innovations, indicators based on patents or $R \& D$ expenses are then not adapted. As we have already mentioned, trademarks are a part of firms' marketing strategy and as such they could bring information on marketing innovation.

To sum up the various ideas mentioned in this introduction, we assume at this point that trademarks could be informative on innovation at two different levels. First, they could serve as a proxy for product innovations, as they are often associated to the commercial launch of new products. As such, they would complement the information given by the other indicators which focus on the technological change at the expense of the commercial aspect, and which do not hit certain economic sectors, especially services. Secondly, as brand strategy and marketing strategy are closely related, trademarks could bring information on marketing innovation, for which the other indicators are not adapted.

The purpose of this paper is to explore the object trademark and its potentialities as a statistical tool to measure innovation. The first section defines trademarks and summarises the main legal aspects of the trademark system. The second section presents an overview of the existing literature concerning trademarks and their link to innovative activities. The third section explores some statistical properties of trademarks, and presents the various drawbacks and biases that have to be taken into account and as far as possible corrected when using trademarks as an innovation indicator. 


\section{DEFINITION AND LEGAL ASPECTS OF TRADEMARKS}

\subsection{Defining trademarks}

The article 15 of the Agreement on Trade-Related Aspects of Intellectual Property Rights ${ }^{2}$ (TRIPs) provides a definition of trademarks (TM), stating that "any sign, or any combination of signs, capable of distinguishing the goods or services of one undertaking from those of other undertakings, shall be capable of constituting a trademark."

There are three dimensions in this definition.

- First of all, a TM is defined in substance: a sign. There is no particular restriction on what kind of sign is eligible for registration: it can be denominations, letters, numerals, figurative signs, combinations of colours, sonorous signs, or any combination of those elements. Some jurisdictions may nevertheless require that signs be visually perceptible.

- Secondly, a TM is defined by its function: uniquely identify and distinguish goods or services of one undertaking from those of other undertakings. Hence the sign has to be distinctive. Originally TM law was designed to fulfil the public policy objective of consumer protection. It prevents the public from being misled as to the origin or quality of product.

- Thirdly, a TM is defined in legal terms: it is a type of industrial property, i.e. it is susceptible of being protected by the law so that the owner of the TM has the exclusive right of using it. Practically, the owner can be any natural or legal person.

In practice, trademarks are used by individuals or firms to distinguish their product from other similar products on the market. Trademarks enable them to build customer loyalty, so that people will always buy the same brand for a product, and they also enable them to advertise widely and attract new customers.

Trademarks are alternatively called "brands", this term being more commonly used in the marketing literature. The term trademark refers more specifically to the legal object, whereas the terms "brand" and "branding" are more related to the commercial use and the customer's perception of the mark.

\subsection{Rights and duties associated to trademarks}

A registered trademark grants the owner exclusive rights to use the trademark in the country where the trademark is registered and for the goods/services for which it is registered.

The trademark owner has a monopoly right as nobody else can legally use identical or similar signs for goods or services which are identical or similar to those for which the trademark is registered. If someone else seeks to use the registered trademark (or a similar one) without the owner's agreement, then they can be sued for infringement.

Trademarks are national titles, and the protection applies only in the country where the TM was registered, which corresponds to the territoriality condition.

2. The Agreement on TRIPs, administered by the World Trade Organization (WTO), sets down minimum standards for intellectual property regulation. It was negotiated at the end of the Uruguay Round of the General Agreement on Tariffs and Trade (GATT) in 1994. 
Besides, the TM is registered for one or several classes of products. The protection concerns only the products of the class for which it is registered, except for certain well-known trademarks which benefit from protection beyond the registered classes (see Box 1). The fees are increasing with the number of classes of products for which the TM is protected. Each TM registration office has a classification of products. Most of them now apply the international classification, established in 1957 by the Nice Agreement concerning the International Classification of Goods and Services for the purpose of registering trademarks.

After registration, the TM is protected for a limited period of time (at least seven years, generally ten years). The registration can be renewed indefinitely, upon payment of a fee, if the owner needs further protection.

As for any property right, the registered TM can then be bought and sold throughout the territory where it is registered. In most jurisdictions, a trademark may be sold or transferred with or without the underlying goodwill which subsists in the business associated with the mark. This is not the case however in the United States, where a trademark registration can only be sold and assigned if accompanied by the sale of an underlying asset, for example the machinery used to produce the goods that bear the mark.

The owner of a registered trademark can also license third parties to use the TM, through a license or franchise contract. In that case, it is the duty of the licensor (usually the trademark owner) to monitor the quality of the goods being produced by the licensee to avoid the risk of trademarks being deemed abandoned by the courts.

Besides, in most jurisdictions, trademark rights must be maintained through actual use of the trademark. Failure to actively use the mark, or to enforce the registration in the event of infringement, may expose the registration to removal from the register after a certain period of time. All jurisdictions with a mature trademark registration system provide a mechanism for removal in the event of such non-use, which is usually a period of three years. It is considered as an abandonment of the mark, whereby any party may use the mark. An abandoned mark is not irrevocably in the public domain, but may be re-registered by any party which has re-established exclusive and active use, and must be associated or linked with the original mark owner. This constitutes an element of guarantee that trademarks reflect well the present situation of the market. ${ }^{3}$

\section{Box 1. Protection of well-known trademarks against "dilution"}

Recently (since the 1990s), certain TM laws have been modified to take into account, in certain cases, the damages that may be caused by the use of similar trademarks in other non-competing markets. This corresponds to protection against "dilution". This means that for some well-known TM, infringing use may occur when the TM is used in relation to products or services which are neither identical nor similar to the products or services in relation to which the owner's mark is registered, but this use may damage the reputation of the TM or make it lose its capacity to signify a single source. This kind of protection is mentioned in the TRIPs, article 16 .

3. On the matter of actual use of trademarks, note that certain jurisdictions, notably the United States, contain a requirement of actual use for application as well, although the TRIPs (Article 15) state that it may constitute a condition for registrability, but it should not be a condition for filing an application for registration. 


\subsection{Trademark systems and procedures}

\section{Core registration procedure}

The procedure to register a trademark is quite homogeneous across countries. After the applicant has filed the application with the trademark office, some examiners investigate if the sign fulfils the conditions in order to be protected as a trademark ( $c f$. Appendix 3, Conditions of registrability). Among those conditions, the trademark must not be similar to an already registered trademark, which would produce confusion. The trademark is then published for opposition so that third parties may oppose to the registration of the TM within a period of a few months (generally three). If no opposition is raised during this period, the TM can be registered, for a limited period of time (generally ten years), renewable indefinitely. The amount of administrative fees required to register a trademark differs widely from one Office to another (from USD 60 in the Republic of India to USD 1730 for a European Community trademark).

Although the procedure to register a trademark is fairly harmonised across countries, especially since the TRIPs Agreement, some differences remain between the various jurisdictions. One important difference is to be found between registration systems and Common law systems. Some jurisdictions, notably in the Common law countries, offer protection for the trademark even if it has not been registered, through the tort of passing off. Some countries on the contrary have pure registration systems, like China; they do not recognise TM rights arising through use. In jurisdictions offering protection for unregistered trademarks, it is still much easier for trademark owners to enforce their rights if the trademark has been registered.

The various specificities of trademark legal systems have an impact on the number of applications and their characteristics. Those specificities must then be taken into account in the analysis of trademark data, especially in international comparisons. More details on the specificities of the various national and regional legal systems are presented in Appendix 5.

\section{International agreements}

Various international treaties have been established in order to harmonise the different TM registration procedures across countries, and to simplify the application process for applicants targeting multiple countries. Besides the Paris Convention and the TRIPs, which harmonise the trademark procedure across countries, the most important international agreement for trademarks is the Madrid Protocol, which allows trademark owners to ask for protection in several countries by filing only one application. Yet, it is not possible to file a single trademark registration which would automatically apply around the world. In the European community, since 1994, trademark owners can register a trademark which is valid throughout the European Community, through the Community Trademark (CTM) system. The various international Agreements concerning trademarks are detailed in Appendix 4.

Thanks to the various international treaties, the trademark systems are relatively harmonised world wide. Besides, thanks to the registration systems, trademark datasets are available with information on the owner, its geographical origin, and the dates of application and registration. Then trademark data are susceptible to be subjected to various economic analyses. The following section presents an overview of the principal economic studies focusing on or referring to trademarks, and in particular those related to their links with innovation. 


\section{TRADEMARKS AND INNOVATION: LITERATURE REVIEW}

Up to now there have been relatively few economic studies dealing with trademarks, which is a topic more common in the marketing literature. As far as the link between trademarks and innovation is concerned, it has rarely been analysed. The following section presents the main studies in the existing literature dealing with trademarks, and more precisely with their relation to innovation ${ }^{4}$.

\subsection{The use of branding in the launching of new products}

Several lines of studies suggest that trademarks are likely to be involved in the innovation process. To start with, many studies in the business literature mention the importance of branding in the commercial implementation of new products. P. Trott (2005) for example considers that brand names are a key element of the marketing strategy to launch a new product, as well as the other characteristics of the good (technology, packaging, price, etc.). Brands enable firms to inform consumers about products, their quality and also possibly their novelty. Consumers use them to make their choice between competitive offerings, and they can choose to remain loyal to one preferred brand. Brands are then essential to build a stable long-term demand.

According to D.A. Aaker (1991), there are several possible branding strategies for firms to launch a new product. Some firms choose to identify each product with a separate name (e.g. Procter \& Gamble has developed more than 70 separate brands). In contrast, some firms may choose to use an already existing brand and to extend it to the new product (e.g. Yamaha is a brand used at the same time for motorbikes, music instruments, and home electronics).

Both strategies have drawbacks and advantages. Creating a new brand makes it possible to construct an image without being associated to anything. This may be advantageous for launching a new product, especially if it is very different from the other products of the company. For example, when Mercedes Benz launched, with the help of the Swatch group, a new line of products, small city-cars, they launched it under a new brand name, Smart (an acronym for Swatch Mercedes Art Cars). If the product had been launched under the Mercedes brand, it would have been more confusing for customers and more difficult to attract their interest, especially as Mercedes is renowned for spacious comfortable cars. Likewise, according to Aaker, the Macintosh computer would not have had a proper image if it had been called Apple 360. On the contrary, Hewlett Packard may have been handicapped by the use of the same brand first for its calculators and then for its computers, so the various product lines are not well differentiated. However, creating a new brand is costly, it implies big communication investments. That is why some firms find it more advantageous to stretch an already existing brand, so as to benefit from the reputation it has already acquired in other markets. This enables firms to launch new products and enter new markets rapidly (e.g. the Virgin group has launched many products on various markets always using the same Virgin brand).

4. One central question in the economic analysis of trademarks, which has divided the economists, is the question of the impact of trademarks on social welfare (see Box 2). However, this question has no link with the issue of the quality of trademarks as an innovation indicator. What matters in this issue is simply to know whether the deposits of trademarks by firms are actually correlated to their innovative activity, independently of the positive or negative consequences. 
As a consequence, there are various types of relations between brands and products ${ }^{5}$, going from the brand associated to a single product (Tic-Tac), to the brand associated to a sample of many products (Danone). Hence the perimeter of what is designated by a brand is relatively vague. The link between a brand and a product is not a one for one link. Some innovations may not be associated with a specific brand. However, according to Aaker (1991), pioneer innovations are generally related to a new brand name. An American study led on various market segments has shown that nine out of eleven brands in a pioneer segment were new brand names. The remaining two were brand extensions that have failed. Moreover, various surveys have shown that the more mature the market is, the more the strategy of brand extension is used by new entrants on the market. In markets that are new or still developing, the product brand strategy is more adapted because it enables firms to take some risks: if a product does not work, it will not damage the reputation of the other brands of the firm ${ }^{6}$.

\subsection{Brands as barriers to entry}

Depositing a new brand name, besides, enables the firms to appropriate the benefits of their innovation. According to J.N. Kapferer (1991), brands are used by innovative firms to pre-empt a positioning. Indeed the brand becomes the nominal reference for the innovation; "the brand name patents the innovation". Several authors in the marketing literature mention the key importance of brands as a barrier to entry of new competitors in a market (M. Baker and S. Hart, 2007; J.N. Kapferer, 1991). They enable firms to create customer loyalty, which means that people will keep on buying the same brand for one product.

5. J.N. Kapferer (1991) identifies six main patterns of relations between brands and products:

- Product-brand: one name is associated to a single product. This strategy is frequent in the hotel business (e.g. Accor group), and the food industry. To the extreme, when the product is very specific and has no equivalent, the brand becomes the only denomination for the product (e.g. Malibu, Tic-Tac, Bounty...); it is then called a branduct (Swiners, 1979).

- Line brand: the brand is associated to a line of product, that is to say a set of products complementary to each other (e.g. Calgon sells washing powder and water softening salt).

- Range brand: the products bearing the same brand are related by a common principle, a common concept. This strategy is frequently used in the cosmetic and textile sectors (Benetton), or in industry (Facom).

- Umbrella brand: the same brand is associated to various products in various markets (e.g. Yamaha, Virgin, Palmolive). This enables firms to make scale savings, as all their products and all their communications contribute to their notoriety. The drawback is that a failure in one market might harm the brand in all the other segments.

- Source brand: this is identical to umbrella branding, except that the various products have a proper name. (e.g. Nestlé is the source brand for Crunch, Nescafé, Nesquick). It is however the source brand that distinguishes the product, the underlying brand alone would not be sufficient.

- Endorsing brand: this is identical to source brands, except that the underlying brands distinguish the product. The endorsing brand has only a function of guarantee.

However those definitions are only schematic. In fact many brands correspond to several of those definitions (e.g. L'Oréal is sometimes a product brand, sometimes a source brand, e.g. for the products "Studio Line", and sometimes totally absent, e.g. for Dop products or Lancôme products).

6. Note that brand extensions may also be subject to trademark deposits. For example, "Virgin Cola" is a registered trademark, as well as the single name "Virgin". With the umbrella branding strategy, the firms save money mostly on communication and advertising costs, but not necessarily on the TM deposits themselves. 
Moreover, beyond the marketing literature, some economists have noticed that trademarks may be used by firms to appropriate the benefits of their innovations. The question of appropriability has been the object of a series of papers since the late 1980s, trying to find out empirically what are the mechanisms used by firms for appropriating the benefits of innovation. The results of the "Yale survey" (Levin, Klevorick, Nelson, Winter, 1987) and of its more recent update (Cohen, Nelson, Walsh, 2000) show that there are various strategies of appropriation, varying across sectors and also with the size of the firm. Brand names are one of those strategies.

Trademarks can be used alone, or in addition to other appropriation mechanisms, such as secrecy, lead time, or patents. Some firms notably use them in complement of patents: they build brand reputation during the length of the patent, and then keep the market power thanks to the brand once the patent has expired. This is particularly the case in the drug industry, where trademarked products are often more successful than their generic equivalent. Trademarks may also be used along with secret to protect an innovation - this was notably the strategy of Coca-Cola. They can as well be used to reinforce a lead-time strategy, as they are used to attract the early interest of consumers, notably through intensive advertising. Trademarks may besides be used in order to protect what the other mechanisms of appropriability do not protect, for example the Open Source Software (Lee Davis 2006).

It appears then that trademarks are susceptible to have a link with the development of product innovations. They are used to attract customers through advertising, and to develop loyalty, so that the firm can appropriate the benefits of their innovations. Besides, trademark deposits are linked with marketing innovations.

\subsection{Branding and marketing innovations}

The link between trademark deposits and product innovations is relatively clear and straightforward: the commercialisation of new products is sometimes associated to the creation of a new trademark in order to communicate about the innovation and later, possibly become the reference on the market for the product, which enables firms to appropriate the benefits of their innovation. For marketing innovations, the link with trademark deposits is more complex.

The Oslo Manual lists several types of marketing innovations. Each kind is susceptible to be associated to a trademark or not.

- Innovations in the product packaging or design. Some of those innovations may be associated to a registered brand name. For example, the Cargo Cosmetic Group has registered trademarks for innovating packaging for cosmetics with a unique usage ("Color Card", "Daily Gloss"). Another example is "Ready to roll", a trademark registered by Shewin Williams Company for a painting roll that can stock and distribute painting. Note that some of those packaging innovations may be patented (e.g. Color Card $)^{7}$.

- Innovations regarding the taste or the aspect of the product. Those kinds of innovations may be associated to a registered trademark (e.g. Cherry Coke, Vanilla Coke), yet not systematically (the new tastes of Tic Tac are not registered).

- Innovations regarding the product placement and selling outlets. This is generally not associated to a trademark, except certain companies which specificity is a particular selling circuit, e.g. online trade (Amazon.com, Telemarket.fr are deposited trademarks).

7. Source: Dupont Awards for Packaging ( $19^{\text {th }}$ award winners), website: http://www2.dupont.com/Packaging/en_US/awards/index.html 
- Innovations in product pricing. This might be associated to the registration of a trademark, for example in the telecommunications where pricing is the main element on which firms can differentiate, as they all offer the same kind of service (e.g. "SFR Illimythic", which corresponds to unlimited communication for a fixed rate).

- Innovation in product promotion (appearance of the product in a movie, famous people promoting the brand...). This kind of innovations does not lead to the registration of trademarks.

To sum up, except innovation in the product promotion, all kinds of marketing innovations are susceptible to lead to the registration of a trademark. Indeed, they correspond to incremental innovation on certain characteristics of the product that the consumer is likely to value per se: better packaging, a new taste, new pricing, a new selling outlet. Then, as for product innovations, it is in the interest of firms to shed light on those innovations so as to attract customers, and this might be achieved through the creation of a brand. Some methods of customer relationship are for example registered (e.g. "Le contrat de confiance" by Darty, "one-click" by Amazon).

Besides, the creation of new brands is likely to bring in return marketing innovations. Indeed, according to the marketing literature, the building of a strong brand involves differentiating from other competitive offers. According to R. Elliott and L. Percy (2006), various marketing innovations may be used to achieve this differentiation, e.g. innovations concerning distribution outlets (e.g. Pizza Hut mini-stores in supermarkets), packaging, the use of cause-related marketing, celebrities associated to the promotion of the product, or also the "fashionisation" of functional objects (e.g. Nokia selling mobile phones with a huge range of alternative covers). This enables firms to attract new customers for the brand or to adopt a certain positioning. Hence the use of trademarks by firms gives them an incentive to do some incremental, marketing innovations in order to distance themselves from competitive products.

So in a double way, trademark deposits are likely to have a link, although not systematic, with marketing innovations; hence they might serve as an indicator of those innovations.

In the light of those previous analyses, there are reasons to think that trademark deposits are related to innovative activity, be it product or marketing innovations. And yet, relatively few studies have considered trademark data as an indicator of innovation. Generally speaking, relatively few empirical studies have been conducted on trademarks until now, which is surprising considering the high number of data that are potentially available. Only a few authors have tried to explore those data and relate them to other economic variables.

\subsection{Statistical studies on trademarks}

\section{At the aggregate level: global distribution of trademark deposits}

First, some authors have tried to relate trademark data with various economic indicators at the aggregate level. Baroncelli et al. (2005) for example conducted a study for the World Bank analysing the global repartition of trademarks. In this study they look at registrations filed by the Madrid protocol across one hundred countries, over the period 1994-1998. They compare the frequency of designation of various countries by trademark applicants to the import and export shares of those countries. They notice that the countries which register the most trademarks abroad are the same that export the most (that is also the countries with higher level of income). They argue that the exporting activity implies a need to be recognised abroad, which explains why the exporter countries use relatively more trademarks abroad. They find however that the global distribution of trademarks, although skewed towards countries with higher level of income, is not as uneven as the global distribution of patents. Indeed firms in developing countries may be more likely to differentiate themselves by investing in brands rather than in new technologies, which are more costly. 
DSTI/DOC(2009)6

\section{At the firm level:}

\section{Trademark deposits and firms' performance}

Several studies have besides analysed the relation between trademark deposits and other economic variables at the firm level. Some authors have notably studied the correlation between trademarks and the economic performance of the firm, measured by sales, market value or profit, finding a significant positive impact (Seethamraju, 2003; Griffiths et al., 2005). Some authors explain this partly by the fact that trademarks are a proxy of innovation. Greenhalgh and Rogers (2007), who find a significant positive impact of trademark activity on stock market value and productivity levels in UK firms, explain that trademark activity proxies a range of other unobservable firm characteristics, notably innovation, that raise productivity and product unit values. Griffiths et al. (2005) also consider that trademarks proxy innovation. They used trademark deposits as an indicator of innovative activity, next to patents and designs to investigate the relationship between firms' profits and innovative activity.

However, in those papers, the link between innovation and trademarks is not modelised explicitly. The positive impact of trademarks on the performance of firms is certainly not only due to their link with innovation. For example, the registration of a new trademark is also likely to have a positive impact on the commercial success of firms, notably by opening new advertising opportunities. Then further verifications need to be done to be able to assess the link between trademarks and innovation. A few papers have focused on this link more precisely, and have sought to verify empirically that trademarks are related to innovation.

\section{Trademark deposits and innovative activity}

A first verification of the link between trademark deposits and innovative activity is found in a paper by Allegrezza and Guard Rauchs (1999), which analyses empirically the determinants of trademark deposits by firms. Their study is based on a survey of 2500 Benelux SMEs from the Benelux Trademark Office (BTO). They find a positive relationship between trademark deposits and the size of the firm, the intensity with which the firm watches its competitors, the firm's estimation of its competitors' ability to imitate its products, the percentage of exports in turnover, the subjective importance given by decision makers to trademark protection, and also they find a significant positive relationship with R\&D intensity, measured by the frequency with which the firm undertook R\&D activities. There seems then to be a link between trademarking activity and innovative activity, proxied by R\&D. This link was verified by several authors afterwards.

Schmoch (2003) explores the potentials of marks as an indicator of innovation especially in the service sector. According to him, the analysis of the service sector is made difficult by a lack of appropriate statistical data. He mentions that trademarks, contrary to patents, apply to services as well as products, so they open up the area of services. Schmoch (2003) tests whether trademarks are indeed correlated to innovation in the service sector. His study is based on a survey led by the Center of European Economic Research (ZEW) of 377 German firms in knowledge-intensive services in the year 2001. Based on the results of this survey, he estimates the relation between trademark use and innovative activity, controlling for the sector, the investments in R\&D, the export shares, and the share of university/vocational school graduates, using the share of turnover associated to new products, as a proxy for innovative activity. He finds a positive and significant correlation of trademarks with innovation in the knowledge-intensive sectors, and in the service sector in general, whereas the correlation of patents and innovation in this sector is little significant. Schmoch concludes on this basis that trademarks meet all the preconditions to constitute an indicator for service innovation, as they are practically ready for statistical treatment and are highly correlated with the target variable. 
Then a study by Mendonça, Pereira and Godinho (2004) extends the analysis to innovation in general, not limiting it to the service sector. They present descriptive statistics on Community Trademarks data, their evolution, repartition by country of origin, by classes, and find that applications for service trademarks boomed in the 1990s, a trend led by knowledge-based services. To get more information on the characteristics of trademark behaviour and to assess the link with innovation, they analyse the results of a survey of Portuguese firms on business attitudes towards Intellectual Property Rights (IPRs). They find in every sector a positive correlation between the use of patents and the use of trademarks. They notice furthermore that the higher-tech sectors, which are characterised by fast-growing technologies, tend to use more trademarks than lower-tech sectors. Those two observations lead them to state that trademarks can be seen as an additional indicator of innovation next to the other traditional indicators.

Lastly, another attempt at evaluating the possibility of using trademark statistics as an innovation indicator was made by Malmberg (2005). His studies adopt a longitudinal approach, and compare trademark registrations with the launch of new-to-the-firm products for several firms in different sectors the electromechanical, automotive and pharmaceutical industries - on a period of time of 60 years for the pharmaceutical sector, and 15 years for the other sectors. He finds very different results across the sectors. For the electromechanical and automotive sectors, the number of trademark deposits appears not to be related to the number of new products. According to the author, this is due to the fact that firms in those sectors are often relying on model numbers to identify their products, and these model numbers are seldom registered as trademarks. On the other hand, the numbers of trademarks and of new products seem highly correlated in the pharmaceutical industries, indicating that most of the new products have been trademarked. More generally, the author mentions that trademarks are likely to be well-related to innovation in industries with frequent use of trademarks and with products targeting consumers.

All those studies suggest that trademarks could reflect various types of innovation. There are reasons to think that they are related to marketing and product innovations. Existing empirical studies tend to confirm this assumption, as trademark deposits are generally highly correlated with other indicators of innovation, be it patents or share of innovative sales. However, those correlations are not a sufficient guarantee that trademarks are a proper innovation indicator. Raw trademark statistics would constitute a very biased and noisy indicator of innovation. A certain number of issues have to be taken into account and, as far as possible, resolved to possibly use trademark statistics to appraise innovation. 


\section{Box 2. Trademarks and social welfare}

The question of the impact of trademarks on social welfare has been subject to divergent opinions among economists. Landes and Posner (1987), in their founding paper of the "Law and Economics Approach", argue that trademark law can be explained on the hypothesis that the law is trying to promote economic efficiency. The basic argument is that trademarks are economically beneficial since they help to solve the information asymmetry issue between sellers and buyers, highlighted by Akerlof (1970). Firms use trademarks to signal to consumers that the product is of a certain quality. Landes and Posner build a formal model based on the integration of the consumer search costs whilst choosing his products: the full price of the good comprises both the money price and the search costs. The investments of firms in trademarks reduce the search costs, so that the firm can charge a higher money price, and increase its profit. When differentiated quality is introduced, the model also predicts that higher trademark investment goes with higher quality of products. So according to Landes and Posner, trademarks reach a sort of social optimum. They have a value for firms as well as for the entire society at least because they minimise search costs, not to mention the potential subjective value that they represent for consumers.

This vision of trademarks contributing to economic efficiency is challenged in the theoretical industrial organisation literature on brands and barriers to entry. Here, a traditional argument is that firms may use product or brand differentiation to create barriers to entry by incumbents and receive monopoly rent. This question is explored in a paper by Economides (1988). He acknowledges the advantages offered by trademarks as regard the facilitation of consumer decision and the creation of incentives to quality, but next to those advantages trademarks may give rise to certain market distortions. According to him, trademarks open competition in a new dimension: the marketing, and the corresponding mental images. Two distortions can arise from this context: first, the ability to differentiate, when associated to advertising, creates monopoly power which may lead to a too high number of firms entering the market; this is an issue in markets where the entry of too many firms is under-optimal, industries with high fixed costs for example. Secondly, a distortion may appear in purchasing decisions, the consumers being misled by the mental images. However, Economides does not acknowledge this second point, arguing that the perceived images produced by marketing are properly valued by consumers. Concerning the barriers to entry, the analysis of Economides concludes that the effect of brand loyalty is ambiguous, and that nothing can be asserted either on the beneficial or detrimental nature of trademarks on social welfare. On the one hand brand loyalty tends to reduce the number of differentiated products (if advertising has intertemporal effect). The effect of that on welfare is ambiguous, either it leads to reduce the too high number of brands, or it supports too much oligopolistic advantage. On the other hand, with sequential entry (one firm enters at a time), the profitability of a potential entrant is determined by the deterrence strategies of the incumbent but also by the ease with which further entrants will be deterred. Thus, if the deterrence technology is cheap, it may be more expensive to deter a high expecting profit entrant than to let it enter. Hence, if perceived advertising is deemed a cheap deterrence technology, they can lead to a higher number of brands than without.

\section{TRADEMARK DATA AS AN INNOVATION INDICATOR: PRELIMINARY STATISTICS AND METHODOLOGICAL ISSUES}

In this section, we present some preliminary aggregate trademark statistics, which illustrate the various advantages of trademark data in measuring innovation, and we also point out various methodological issues that have to be taken into account when building indicators based on trademark data.

\subsection{General trends in trademark activity world wide}

\section{Evolution of the total number of applications worldwide}

The first trademark registrations date back to the middle of the $19^{\text {th }}$ century (see Appendix 1 ). Since then, the number of trademark deposits worldwide has continuously grown over the years, corresponding 
on the one hand to a growing number of offices worldwide (from 9 in 1884 to 116 in $2006^{8}$ ), and on the other hand to an increase in the number of applications inside each trademark office.

Figure 1 presents the sum of the applications received by all the trademark offices worldwide (including the applications received via the Madrid system) every year since 1884 (where the data are available). Note that the configuration of the trademark offices worldwide has considerably changed over the represented period: a lot of offices have been created, and on the other hand some offices have disappeared (notably the national offices of the three Benelux countries, which have been replaced in 1971 by one unique office, the BTO). The creation of the Office for Harmonization in the Internal Market (OHIM), which registers the Community Trademark system, in 1997 has not led to the withdrawal of the national offices, but has however had an impact on the structure of trademark deposits worldwide (the trademarks that were previously filed 27 times in 27 distinct countries of the European Union are now associated to a unique application). Thus, next to the raw data which do not take those evolutions into account, the figure presents in a dotted line the data with a constant perimeter, for the offices where the data were already available in 1884 and which have few missing values ${ }^{9}$. The countries that are included in this sample are Belgium, Denmark, France, Italy, Japan, Switzerland, the United Kingdom and the United States. For the sake of time comparability, the applications at the BTO were added (as they apply to Belgium), and the applications at the OHIM were also added, multiplied by the number of European countries in our constant sample (five countries), as they apply to each of those countries.

Figure 1. Total number of applications received by the Trademark Offices worldwide since 1884

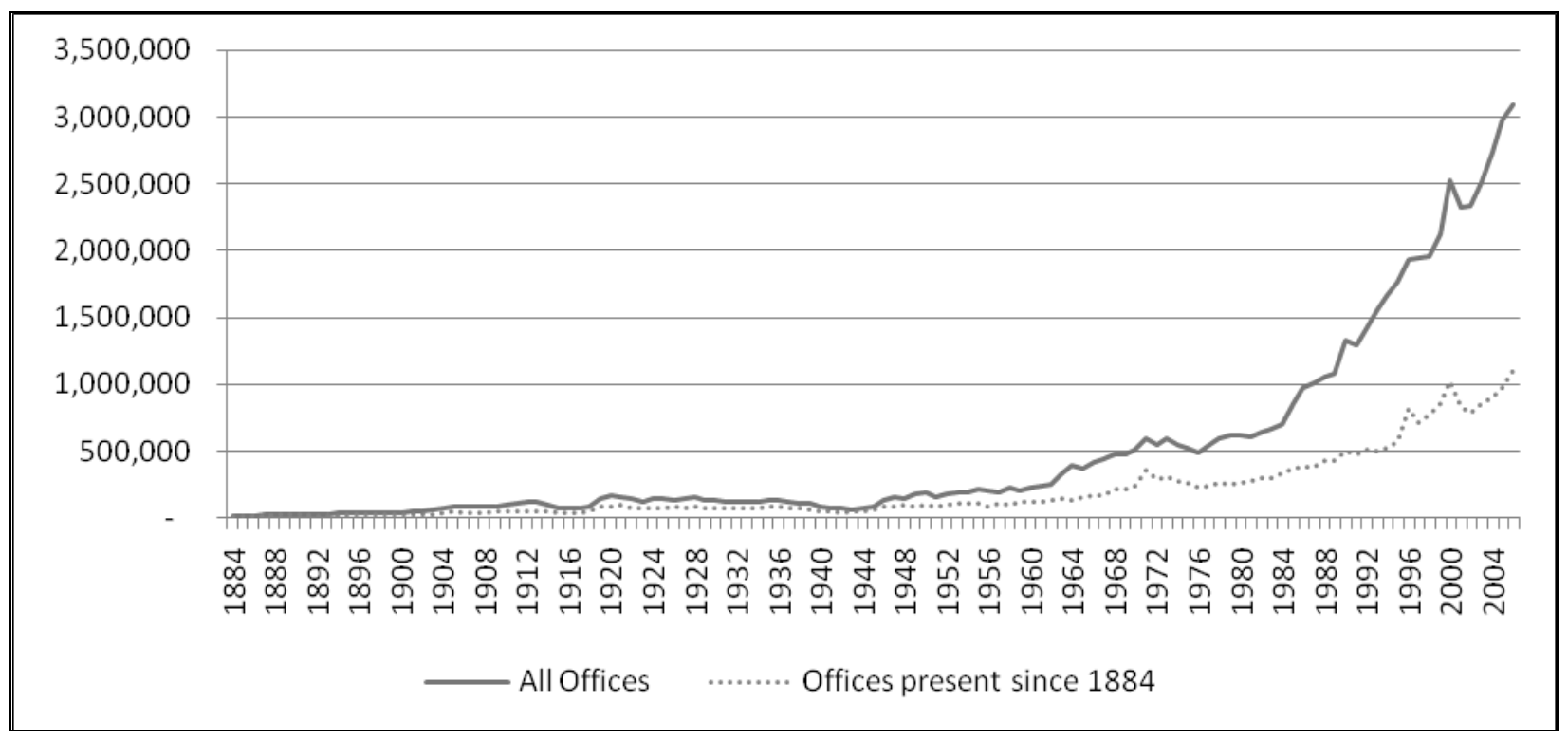

Source: WIPO Statistics Database.

The number of applications has begun to increase after the Second World War, and more significantly since the 1980s, up to more than three million in 2006. This evolution is comparable to that of patent applications, which started to increase in the 1960s and more significantly in the 1980s, reaching around

8. According to WIPO available data.

9. The data series still present some missing values. This can be due to specific circumstances (for example, the French TM office was apparently closed during the two world wars). This can be also due to accounting errors at various levels. The data used here are those reported by WIPO. 
1.8 million applications worldwide in 2006. Currently trademark applications are more numerous than patent applications.

Besides, it appears that, although the growth is roughly continuous, trademark activity is impacted by the general fluctuations of economic activity. Indeed we observe a slowdown in growth in the 1970s, which can be attributed to the general economic slowdown following the oil crises. Likewise, we observe a drop around the year 2000 corresponding to the burst of the Internet bubble.

\section{Geographical repartition of the applications}

Figure 2. Applications in the major offices in 2006

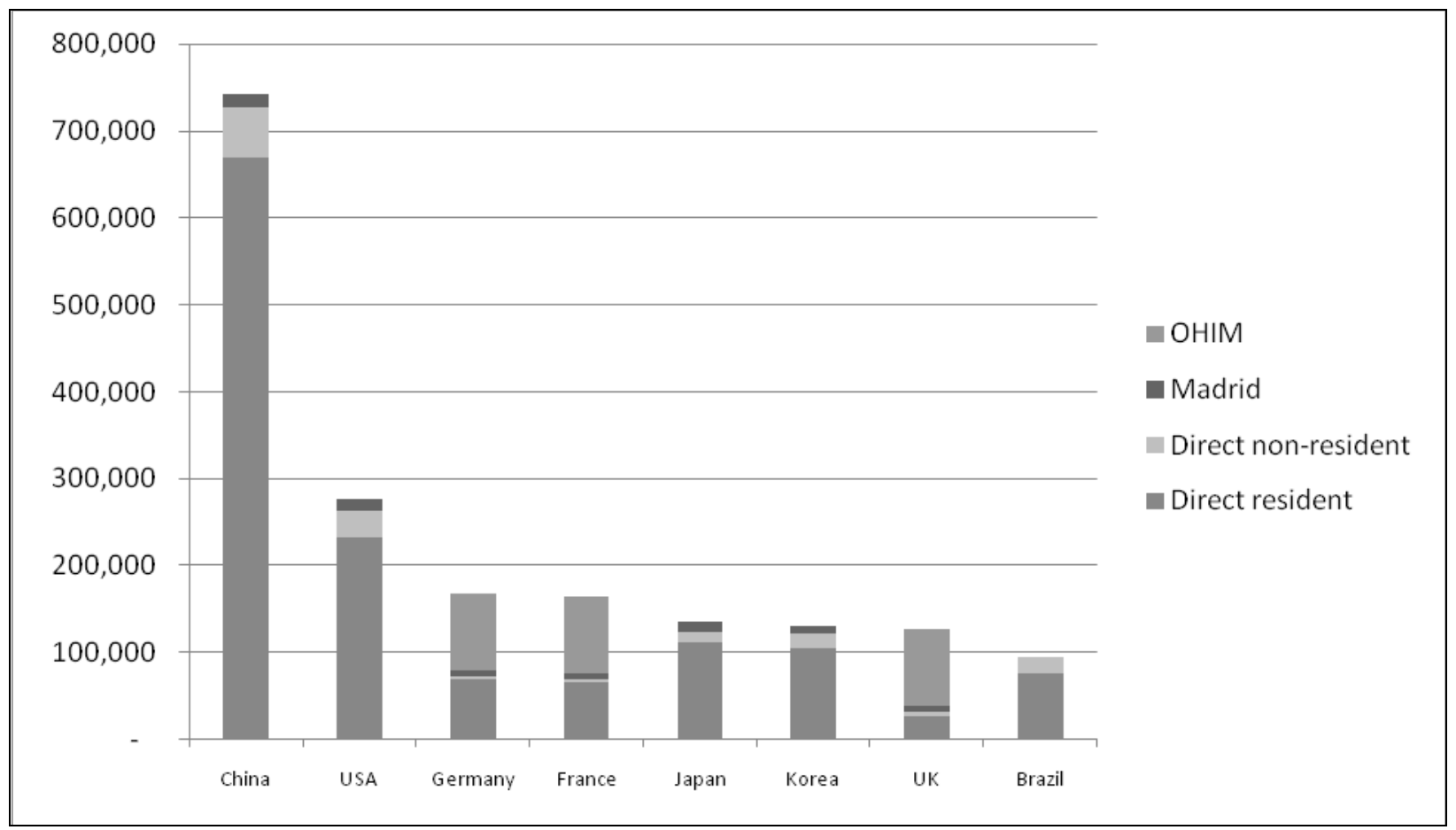

Source: WIPO Statistics Database.

Figure 2 shows the number of trademark applications received in 2006 by the main trademark offices, broken down by routes of application. The CTM applications have been added to the applications in the German, French and UK offices as the protection given by the CTM applies in every country of the European Union ${ }^{10}$.

In terms of geographical zone of protection, the country that attracted the highest number of trademarks in 2006 was by far China, followed by the United States, and then neck to neck Germany, France, Japan, Korea and the United Kingdom. The amount of applications received by China is not directly comparable to the other countries, as China has a single-class application system, which means

10. Note that the aggregation of national and European applications is slightly overestimated as it includes some duplicates, corresponding to the applications filed in a first stage at the national level and later at the European level. On a random sample of 10000 European applications filed in 2006, 4.8\% had already been filed earlier in Germany, 3.6\% in France, and 2\% in the UK. When we correct the duplicate error based on those estimations, the ranking of the various offices remains unchanged. 
that the applicants are allowed to designate only one class of products per trademark application, contrary to other countries that have a multi-class application system. The number of filings in China therefore represents what is counted as the number of designated classes in other countries. China remains nevertheless far beyond the other countries when considering those figures, with 740000 classes designated in 2006 versus 355000 in the United States.

The predominance of China is relatively recent, as we can observe with the trends of applications in the various offices over thirty years (Figure 3).

Figure 3. Evolution of the applications since 1975 in 6 major offices

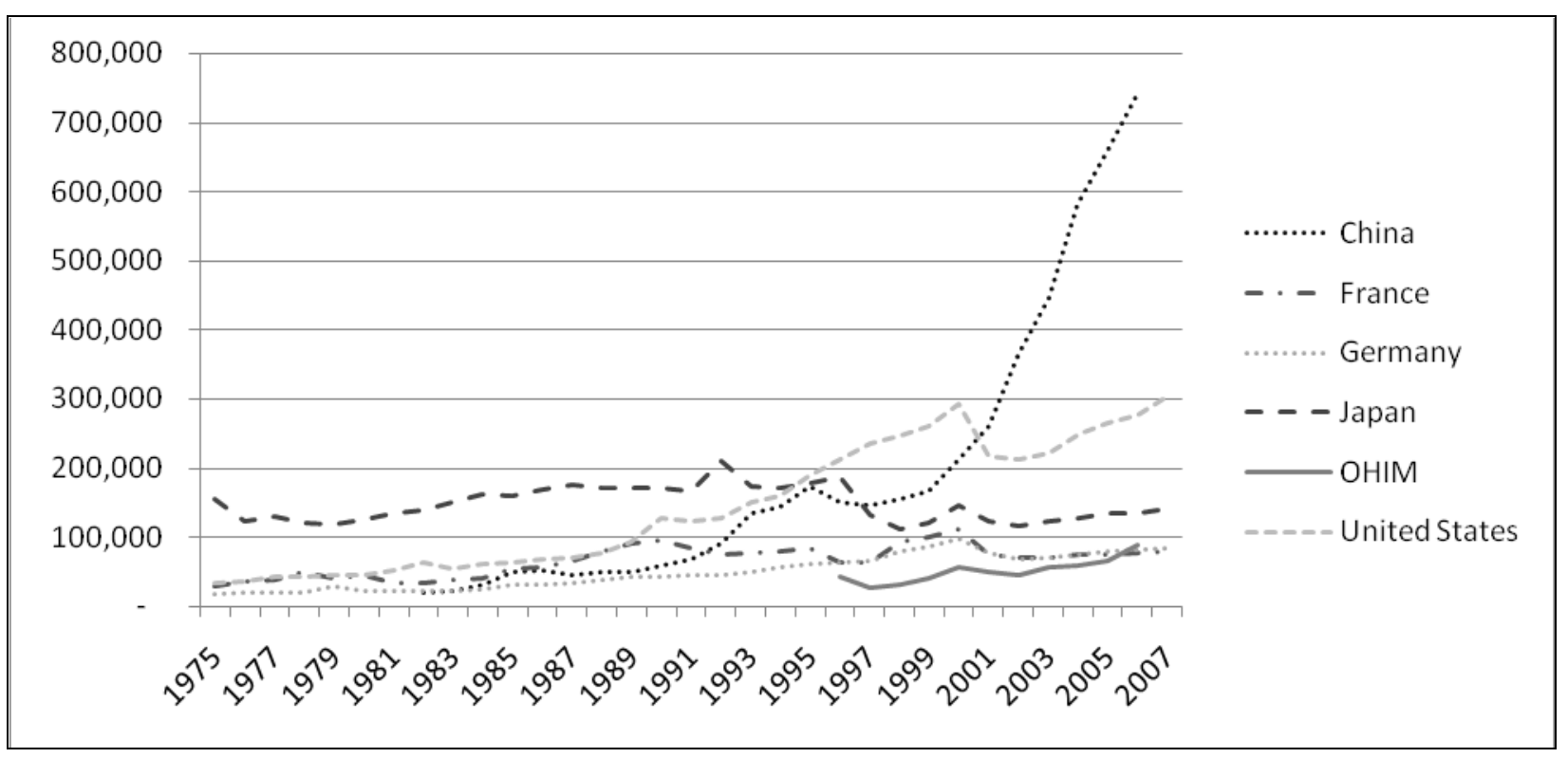

Source: WIPO Statistics Database.

There has been an impressive growth of the Chinese trademark office activity since the late $1990 \mathrm{~s}^{11}$. This growth corresponds to the explosion of the Chinese market, but it can also be partly attributed to the integration of the TRIPs requirements in the Chinese law during the 1990s. This has contributed to making the Chinese trademark system more efficient, so trademark deposits are more profitable for firms ${ }^{12}$. The application of the TRIPs in China has possibly led to a phenomenon of catch-up, the owners of already existing brands registering a trademark in China all at the same time. Indeed, contrary to patents which must remain secret before the registration, it is never too late to register a trademark, even if it has already been used on the market. This catch-up phenomenon could explain the spectacular growth.

With the notable exception of China, most offices show a slight drop in activity around the year 2000, which, as already mentioned, can be explained by the global economic downturn of that period. Otherwise, the number of applications has increased relatively smoothly in all the trademark offices for the last three decades. Yet this is not the case for the Japan Patent Office (JPO), whose position relative to the other

11. Note that the Chinese figures are not directly comparable to the other offices as China has a single-class application system, whereas the other countries have a multi-class application system, as explained in the previous paragraph.

12. See Maskus, Keith, Dougherty and Mertha (2004), about the links between IPR system evolutions and economic development in China. 
offices has been decreasing since the late 1990s, which can be associated to the economic slowdown occurring in Japan since the 1990s. Besides, the creation of the OHIM in 1997 seems to have provoked a slowdown in the trend of national European offices, as the number of trademark applications in the French and the German offices seems to stagnate since the 2000s.

The analysis of trademarks must take into account the specificities of the legal systems (Schmoch, 2003). Legal systems as well as practical conditions of registration vary over time, and this can be misleading when making comparisons. Beside the changes in the configuration of trademark offices worldwide (e.g. the creation of the OHIM in 1997), there are also changes occurring within the national systems. For instance, in the United States it has been possible since 1998 to file trademark applications electronically; this has presumably had a positive impact on the number of applications, as the procedure is facilitated.

The systems vary in time, but also from one country to another, which has an impact on the data of the various offices. For example, if we look at the average number of classes designated in one application, we can observe that the applications at the OHIM designate more classes than at the JPO or at the US Patent and Trademark Office (USPTO): in 2006 the CTM applications designated 2.7 classes in average, against 1.3 for the USPTO applications ${ }^{13}$. This can be explained by the fact that in the CTM registration procedure, the fees are fixed for the first three classes, whereas in the other offices each additional class is payable from the first one. The previous figures are then not comparable, as the context is different.

\subsection{Repartition of trademark activity across sectors}

The repartition of trademark applications is uneven across classes of products. Figures 4 and 5 present the proportion of USPTO and of CTM applications in 2006 designating the various international classes of products and services ${ }^{14}$ ( $c f$. the Nice classification in Appendix 7). Classes 1 to 34 correspond to classes of goods, and classes 35 to 45 to classes of services.

Figure 4. Repartition of the USPTO applications by class of products in 2006

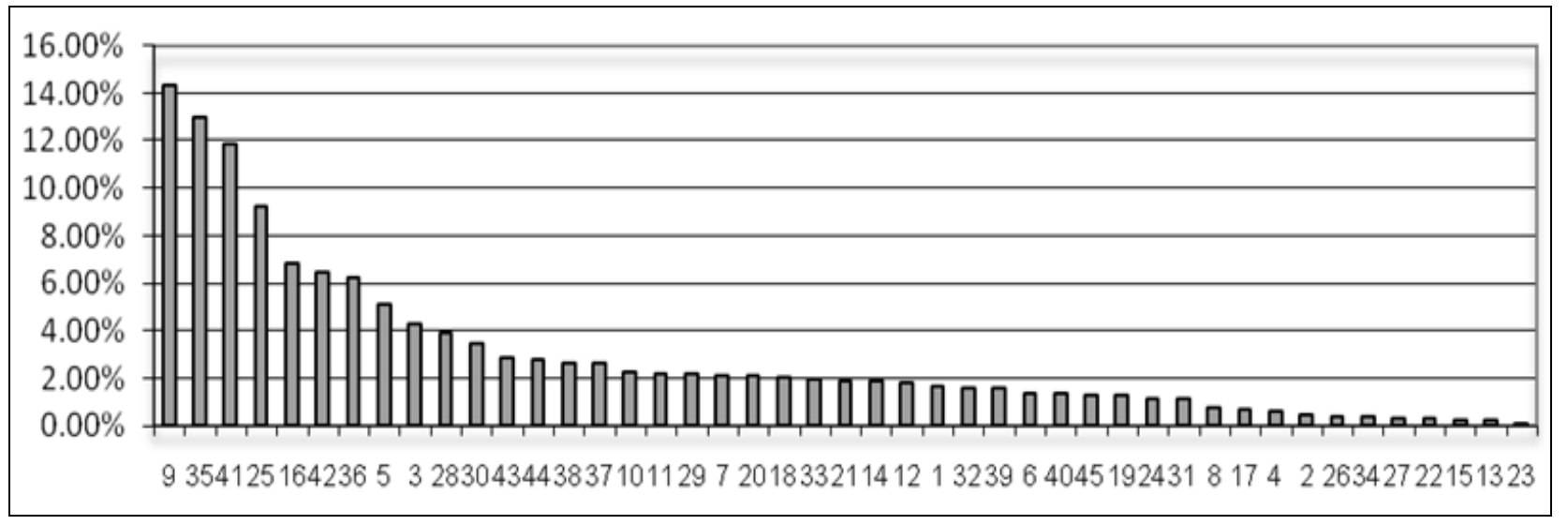

Source: WIPO Statistics Database.

13. Ratio of the total number of designated classes on the number of applications filed, based on the statistics of the OHIM and USPTO annual reports 2006.

14. Ratio of each designated class on the total number of designated classes. 
Figure 5. Repartition of the CTM applications by class of products in 2006

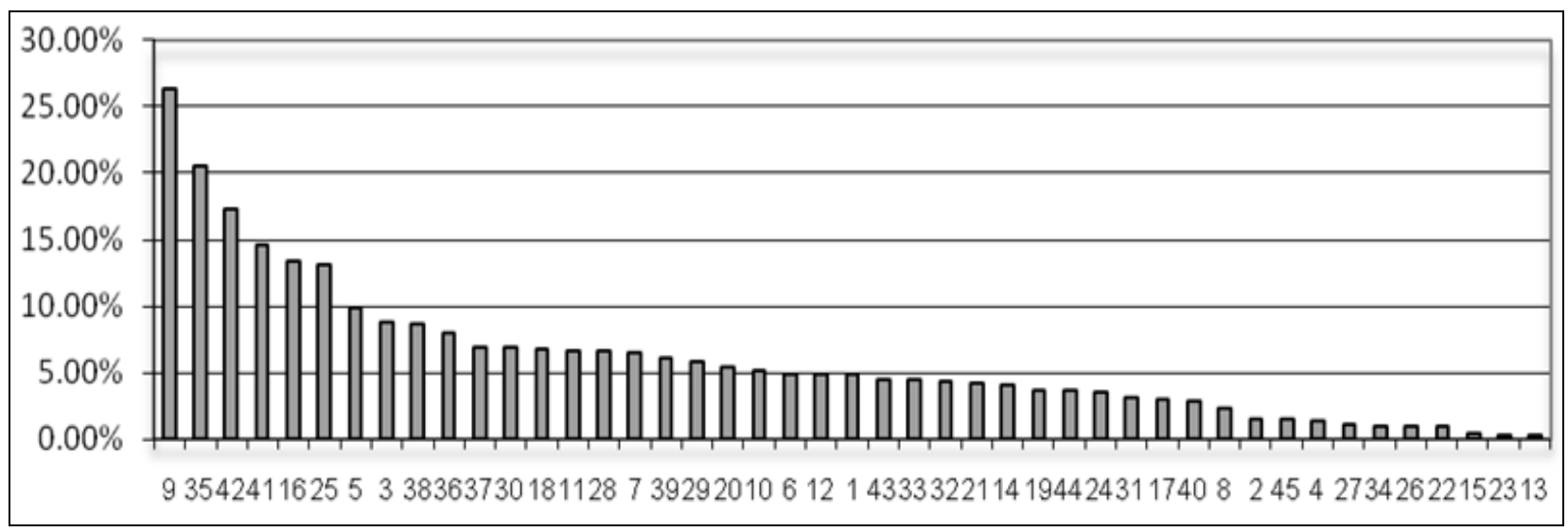

Source: WIPO Statistics Database.

Although they are ranked in a different order, the six most designated classes in trademark applications both at the OHIM and at the USPTO are the same:

- 9: Various apparatus and instruments, notably scientific and medical ones

- 35: Advertising business, management and office functions

- 41: Education; entertainment; sporting and cultural activities, etc.

- 42: Scientific and technological services, industrial analysis and research services, development of hardware and software, legal services

- 16: Paper, cardboard, printed matter, photographs, artists' materials, typewriters and office requisites, etc.

- 25: Clothing, footwear, headgear

Out of those six classes, three correspond to classes of services $(35,41,42)$, which indicates that services have an important place in the trademark activity. This suggests that trademarks might bring information on those fields of products where patent data are lacking.

Besides, we can notice that, beyond the services, trademark applications seem to be numerous in the product fields where patenting activity is low. Indeed, according to Figure 6 representing the patenting activity by industry and R\&D expenses, the industries with the lowest patenting activity are the industries of textile and wearing, and wood and paper. These industries correspond respectively to classes 25 and 16 of the trademark applications, which are among the three major classes of manufacturing products designated in trademark applications. Then it appears that product fields where patenting is relatively low are on the contrary well represented in trademark applications. However, the comparison should be taken with a grain of salt as the correspondence between the classifications is not straightforward: leather products are not associated to textile, and correspond to class 18, and class 16 includes not only paper products, but also minor additional products such as plastic materials for packaging (See Box 4). 
Figure 6. Patenting by industry and business R\&D (PCT Filings 2002-2004)

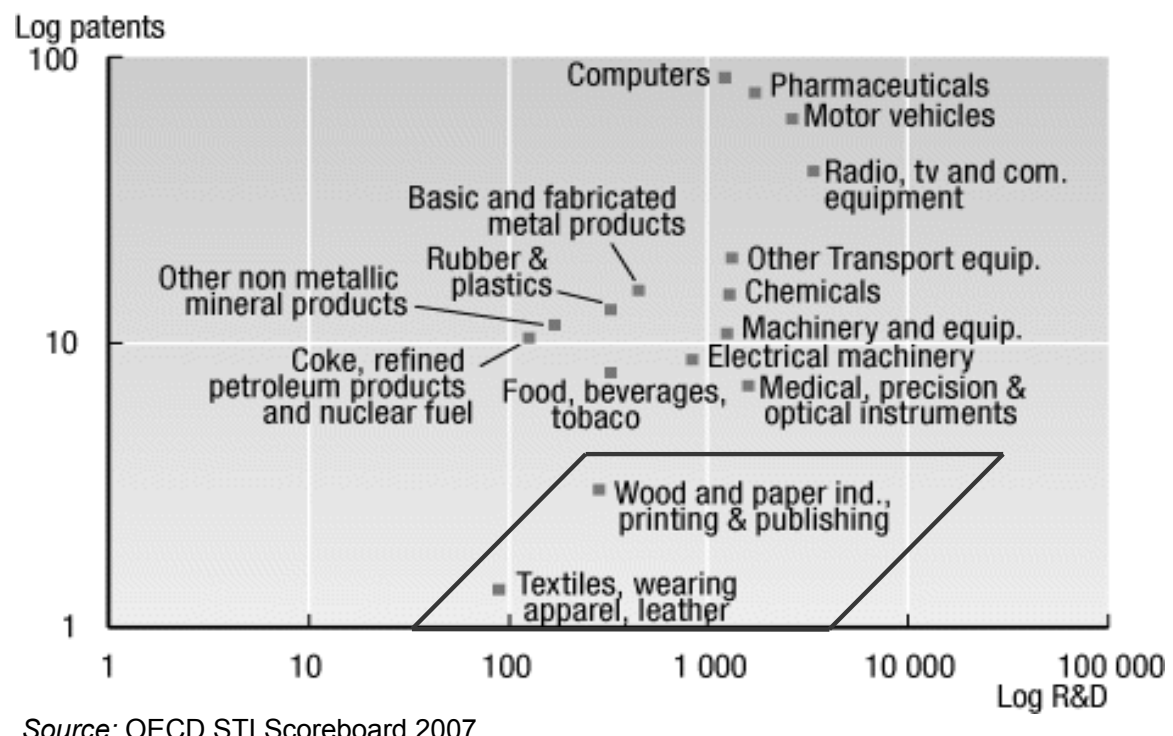

Let's look more precisely at the repartition of the applications between classes of services and products. Figures 7 and 8 represent the evolution of the proportion of trademark applications at the OHIM and at the USPTO designating either exclusively classes of services, classes of goods, or classes of both goods and services.

Figure 7. Proportion of CTM applications designating Services, Goods, or Mixed classes

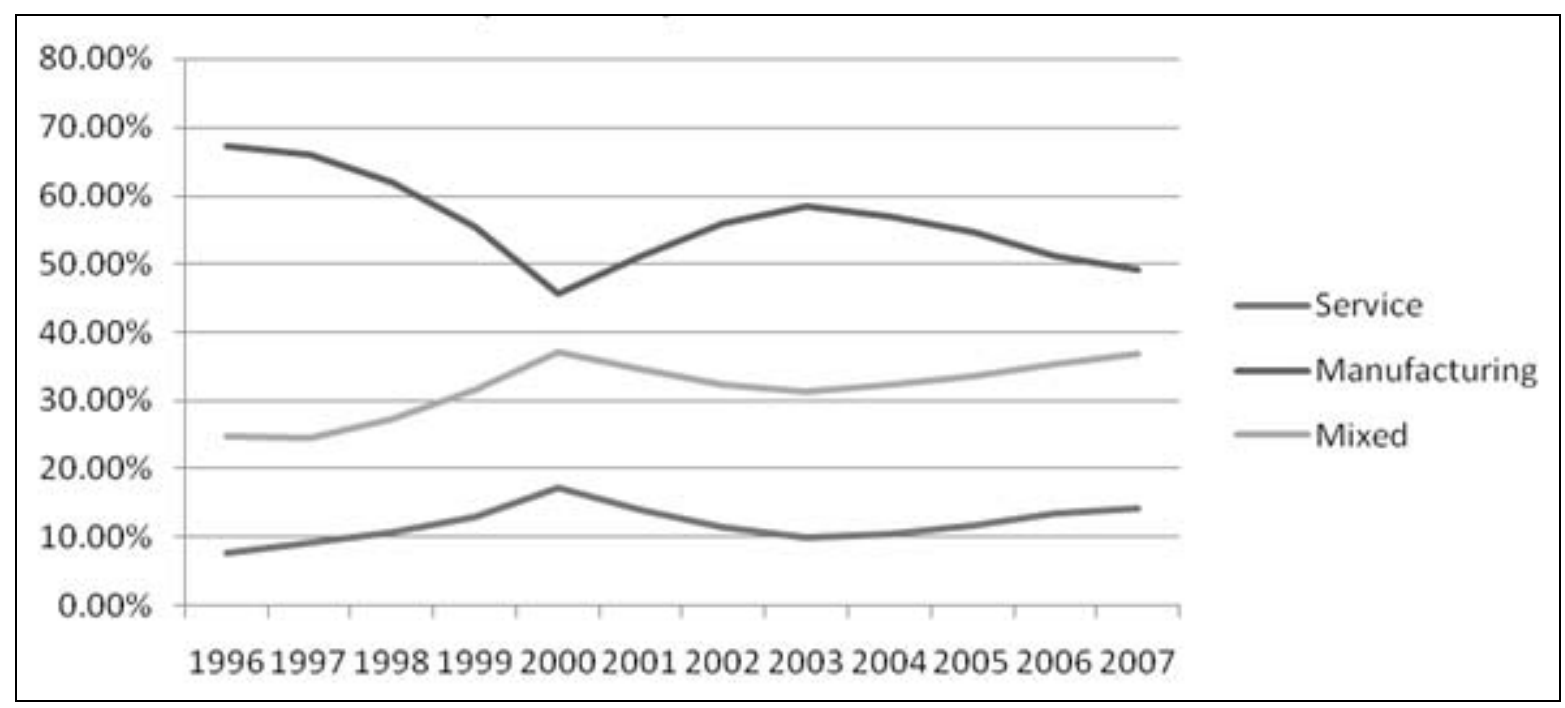

Note: Applications directly at the $\mathrm{OHIM}$, not including applications received via the international route. Source: OHIM online trademark database (CTM-Online). 
Figure 8. Proportion of USPTO applications designating Services, Goods or Mixed classes

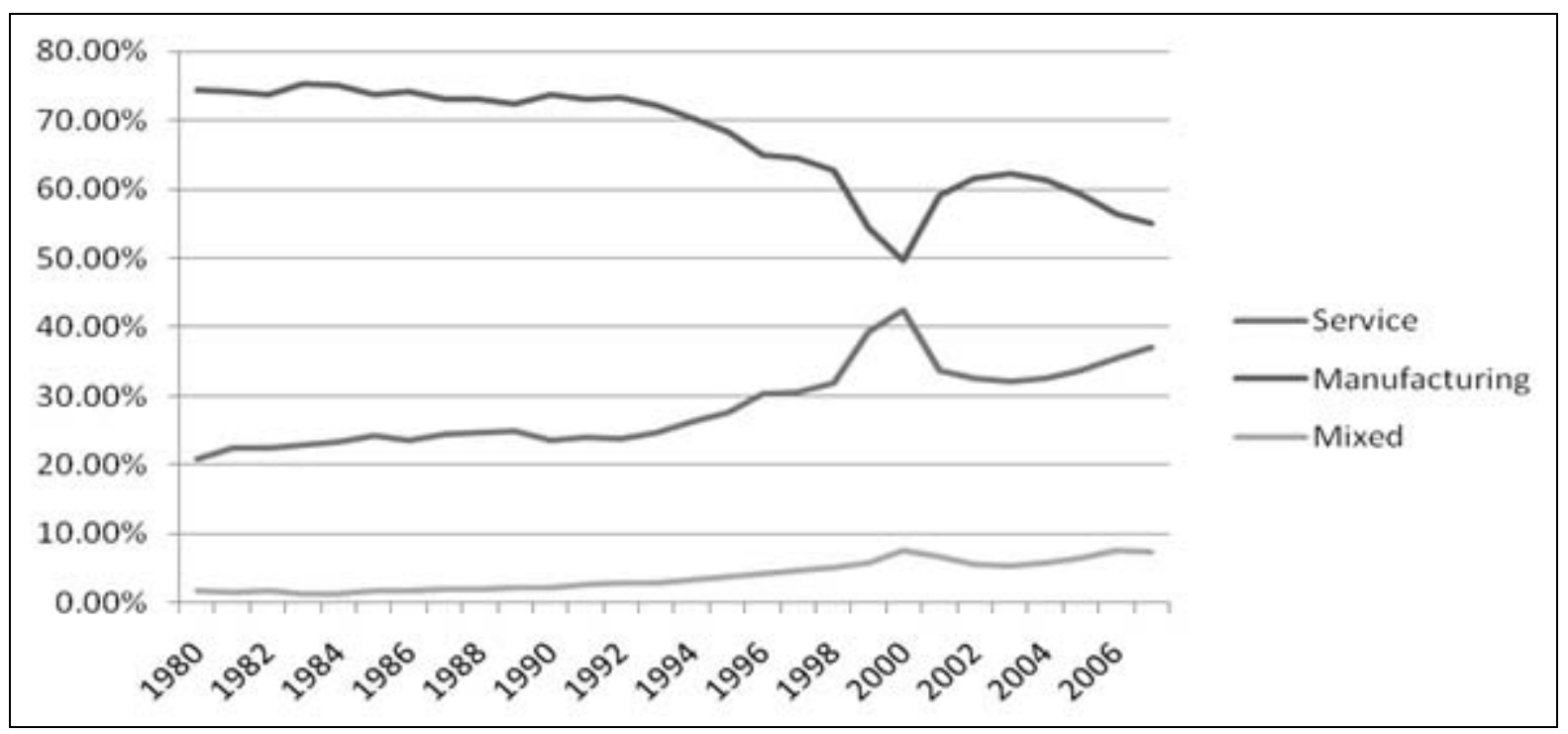

Source: USPTO trademark database (Cassis).

In both offices, the share of trademarks designating classes of services has increased (from $32 \%$ in 1997 to $51 \%$ in 2007 in the OHIM, and from $23 \%$ in 1980 to $43 \%$ in 2007 in the USPTO). This growth corresponds both to an increase in pure service trademarks and in mixed applications ${ }^{15}$. The relative increase in the service applications has been almost continuous in both offices, except during the period from 2001 to 2003, where the proportion of service applications dropped, presumably consequently to the burst of the dot-com bubble. It appears then that services are highly represented in the trademark data, and that this tends to increase over the years, so trademark data could possibly make up for the lack of other innovation indicators.

The analysis of aggregate trademark data must make distinctions between the sectors, as the propensity to deposit trademarks differs from one to another. One can either work at the sector level, or combine trademark indicators with other innovation indicators, notably the other IPRs. Indeed, trademark data seem to be complementary to patent data in terms of sectors. They are very numerous in the non-technological sectors, and in the manufacturing sectors where patenting activity is low. This might indicate that firms use various types of IPRs as various methods to protect innovations, depending on the sector.

15. We can see that the number of mixed trademarks is higher at the OHIM. This can be explained by the fact that, as already mentioned, the average number of designated classes in one application is higher at the OHIM than at the USPTO, because the fees are the same up to three classes. 
DSTI/DOC(2009)6

\section{Box 3. Trademark classifications and sectorial classifications: a concordance table}

The fact that trademarks are registered for one or several classes of products (cf. $§ 1.2$., Rights and duties associated to trademarks) potentially enables sectorial analyses to be made. The classification of products is harmonised between the various systems; most offices now use the Nice classification (arising from the Nice agreement of 1957), which distinguishes 45 classes of goods and services (34 classes for goods, 11 for services - cf. Appendix 7 for a detailed presentation of the classification). However, this classification is not the same as the classifications used traditionally in sectorial analyses (the Nace or the Isic classifications). It may be difficult to associate a trademark with one specific sector. Indeed, classes in the Nice classification are highly aggregate (for example the class 5 regroups among others baby food, veterinary preparations, dental wax and herbicides). Moreover, the trademark classification has been built with a focus on the demand, the customers' side, whereas the Sector classifications focus on the firms' side, on the supply. Lastly, trademarks can be registered for several classes, so some trademarks might be associated to classes of products with which they have no direct link (some trademarks are for example registered in every class).

We can, however, try and see the correspondence between the sectors to which firms belong and the classes in which they register trademarks. An analysis made on a sample of 1000 European firms in various sectors having a TM registered at the USPTO lead to the following conclusions:

First, some sectors are more likely than others to register trademarks. Some sectors present no trademark applications at all, or very few, notably in the primary sector, in transport, in the community social and personal services, and also in the manufacturing of wood, of fuel and electricity products.

Secondly, among the sectors where firms register trademarks, some are mostly associated to one or a few specific classes of trademarks (e.g. firms in the wearing apparels sector mostly register in class 25 , firms in the paper, publishing and printing sector mostly register in class 16) whereas certain sectors deposit their trademarks in various classes (e.g. the sectors of chemicals and of wholesale and retail trade).

Likewise, some classes seem to be strongly related to one sector, whereas some classes seem to be less specific, and are designated by firms from many different sectors. This is notably the case for classes 7,9 and 11 , which all three relate to various kinds of machines or apparatus.

On the whole it is generally difficult to associate an industrial sector to a specific trademark class, as some sectors register in various classes and conversely some trademarks are associated to various sectors. However a clear correspondence can be established for certain sectors and classes, as exposed in the following table.

\begin{tabular}{|l|l|}
\hline \multicolumn{1}{|c|}{ Nace sector } & \multicolumn{1}{|c|}{ Nice classes } \\
\hline 17, 18 and 19: textile, wearing, leather products & $24-25$ \\
\hline 20: wood and cork products & 20 \\
\hline 21, 22: paper products, printing and publishing & 16 \\
\hline 25: rubber and plastic products & 17 \\
\hline 27: basic metal products & 6 \\
\hline 30, 31, 32, 33: electrical and optical equipment & 9 \\
\hline 34, 35: transport equipment & 12 \\
\hline 60, 63: transport and storage & 39 \\
\hline $\begin{array}{l}\text { 67: financial intermediation } \\
\text { 72, 73: computer-related activity, research and } \\
\text { development }\end{array}$ & 36 \\
\hline
\end{tabular}




\subsection{The issue of non-used trademarks}

An issue that should be taken into account in the analysis of trademark data is that not all registered trademarks are actually used on the market. Indeed the deposit of a trademark can be associated to various strategies. It can on the one hand be used in order to signal and effectively sell the products on the market. But on the other hand, many companies file marks that they do not use directly. This can correspond to various strategies. In some cases, firms prior to deciding on a new brand may want to protect several options, and then only ultimately choose one. Besides, some firms may register trademarks only for strategic purposes, without the intent to use them. They may do so in order to block the competitors from using certain names or signs - various descriptive names are deposited in order to limit the possibilities of the competitors, or in order to get licensing rents. They may also do so in order to prevent from tarnishing a brand image (e.g. the firm Red Bull has deposited a high number of trademarks containing the word "bull").

Consequently, some trademarks are never used directly on the market. Those non-used trademarks are however non-negligible. They are, for example, susceptible to reflect the value that firms attribute to certain trademarks, which they really want to protect against tarnishing. The data of non-used trademarks can then bring additional information on the value of the other trademarks (see Box 3).

We can try to appraise this phenomenon and to detect those non-used trademarks. This is made possible by the requirement of actual use, which stipulates that trademarks that are not used continuously during a certain period are deemed abandoned (see paragraph 1.2). We can check that this clause has an important impact on trademarks registered at the USPTO. In the USPTO the trademarks have to be used continuously for six years after the date of registration. Six years after registration, the trademark owner must file declarations with the USPTO showing genuine use of the trademark, if not the trademark is cancelled $^{16}$. A majority of trademarks registered at the USPTO do not survive this duration.

Table 1 presents the proportion (in \%) of trademarks registered at the USPTO between 1987 and 2007 which are still pending or which have died each year after registration. The lines correspond to the dates of registration, and the columns to the date of cancellation or abandonment of trademarks. For each registration year, the years with the highest level of cancellation or abandonment have been highlighted.

16. The Section 8 of the Lanham Act states that :

"Each registration shall remain in force for 10 years, except that the registration of any mark shall be canceled by the Director for failure to comply with the [following] provisions (...). During the 1-year period immediately preceding the end of the applicable time period [6 years for registrations issued pursuant to the provisions of the Lanham Act], the owner of the registration shall pay the prescribed fee and file in the Patent and Trademark Office:

(1) an affidavit setting forth those goods or services recited in the registration on or in connection with which the mark is in use in commerce and such number of specimens or facsimiles showing current use of the mark as may be required by the Director; or (2) an affidavit setting forth those goods or services recited in the registration on or in connection with which the mark is not in use in commerce and showing that any such nonuse is due to special circumstances which excuse such nonuse and is not due to any intention to abandon the mark." 
Table 1. Survival rate of registered trademarks at USPTO between 1987 and 2007

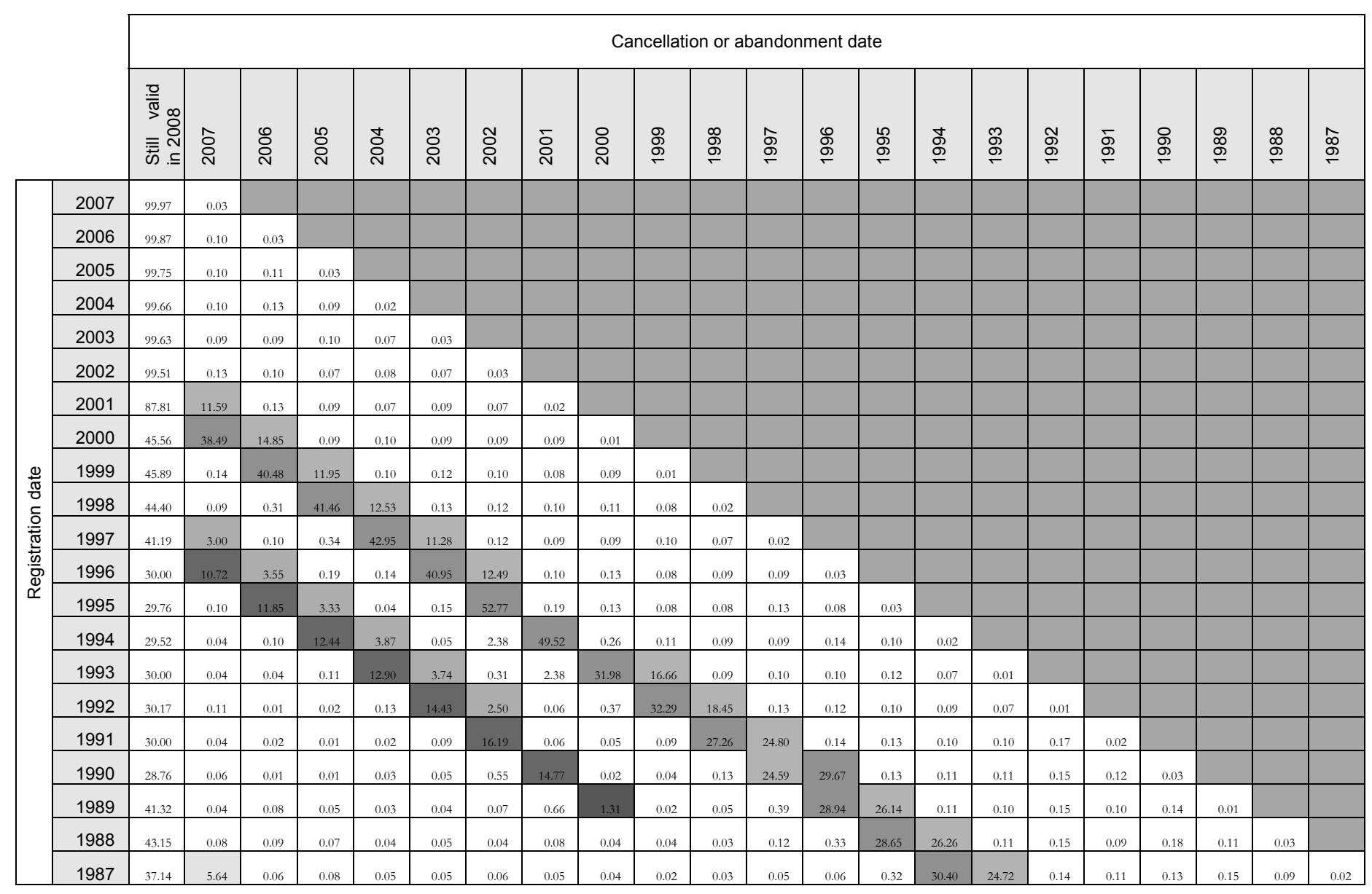

Source: USPTO Trademark Database, OECD calculations.

We observe that a majority of trademarks registered in a given year die six or seven years later. This can be explained by the clause of actual use, which leads to the cancellation of trademarks that have not been used for six years. Note that the trademark owner benefits from a grace period of six months after the six years, which can explain why most applications die seven and not six years after registration (this may also be due to the delays in the cancellation procedure).

The impact of the clause of actual use is quite important. On the whole around $55 \%$ of trademarks die six or seven years after registration. This proportion is very stable over time. Besides, a relatively high proportion (about 15\%) of trademarks die 10 or 11 years after registration; this corresponds to trademarks that were not renewed. Yet the proportion of trademarks dying after ten years is relatively low compared to those dying after six or seven years.

This analysis does not apply to all the trademark systems. Although the clause of actual use is present in almost every jurisdiction, its impact is not always as significant as it is for American trademarks. In the OHIM for example (where the term of cancellation for non-used is three years), around $0.1 \%$ of Community trademarks registered in one year are cancelled every year. There is no particular peak after three or four years, which means that the clause of actual use has no significant impact. The main explanation is that unlike in the USPTO system, the cancellation procedure based on non-use is not automatic for Community Trademarks. In the US, the trademark owner must periodically file declarations 
with the USPTO showing genuine use of the trademark; if not, the trademark is cancelled automatically. By contrast, in the EU, the trademark owner is not obliged to file declarations. Some third party has to come along and apply to cancel the trademark based on non-use. Hence some Community Trademarks have never been used and remain registered. This variation in the procedure explains why the clause of actual use has no significant impact on European trademarks whereas it has on American ones. Nevertheless the history of OHIM trademarks is quite short, and behaviours are susceptible to evolve when the system becomes more mature (notably when the competition on trademarks will become more important; for now only relatively strong brands are registered at the OHIM, which are difficult to attack).

\section{Box 4. The value of trademarks}

As in the case of patents, the value of registered trademarks is very heterogeneous. Many trademarks correspond to marketing or product campaigns that have failed. On the contrary, few trademarks have effectively a very high value for the firm.

Several methods are imaginable to appraise trademark value. A first obvious method is to consider the renewals, high-value trademarks being renewed every ten years. However, this method presents various drawbacks. Firstly, it implies a time-lag of ten years, and secondly it eliminates the non-used trademarks, which fall after a few years because of the clause of actual use. Non-used trademarks are not deprived of any value for firms, indeed they may be used in order to increase the protection of other trademarks.

Another method to appraise the value is to consider the number of oppositions associated to the trademark. If a trademark is associated to a lot of oppositions, this means that many people try to imitate it, and that owners seek to protect this trademark, which suggests that it is valuable.

Another possibility is to consider trademark portfolios. Indeed in certain cases, firms register a set of trademarks related to one effective brand; the others being not actually used. The more trademarks related to one brand are registered, the more valuable the brand is. Indeed it means that firms try to fully protect it from being tarnished or imitated by competitors.

Lastly, those two criteria could be combined (oppositions and non-used protective trademarks) in order to appraise the value of trademarks. 


\subsection{Home bias in trademark applications}

If we look at the breakdown of trademark applications by country of residence of the applicant at the OHIM, the USPTO and the JPO (Figures $9,10,11)^{17}$, we observe that a large majority of the applications come from residents of the concerned zone. In general, the firms which register a trademark start with the home market and later, possibly, go international, which implies an important "home bias" in trademark applications statistics.

Figure 9. CTM applications by region of origin in 2006

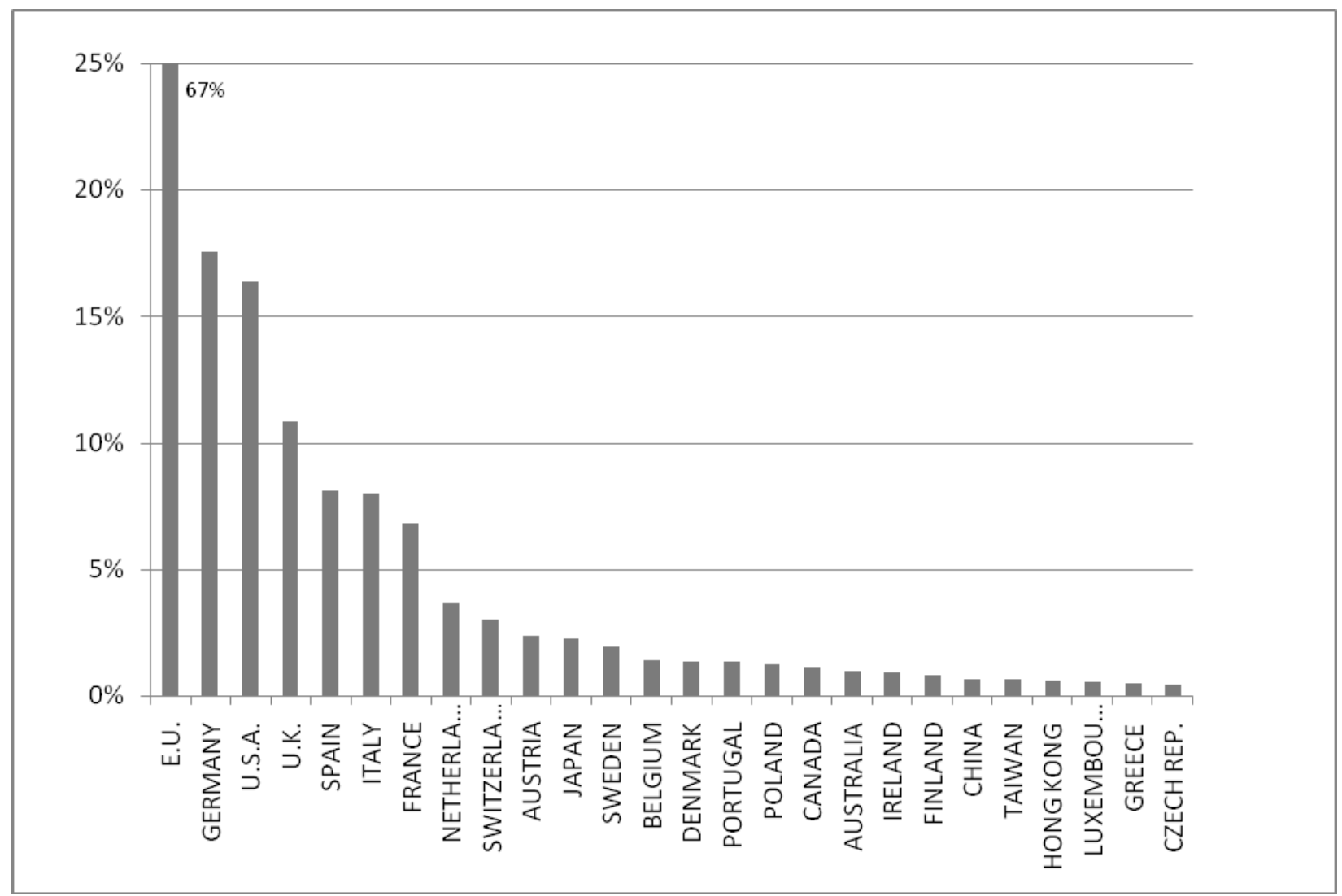

Source: OHIM Annual Report 2006-2007.

17. The following statistics on the origin of trademark applications are based on the figures of the annual reports of TM offices, except for the USPTO as its annual report provides statistics on the origin of applications in terms of total number of designated classes, and not in terms of number of applications filed as in other offices. Then for the US we use the statistics on the origin of applications provided by WIPO, which are in terms of number of applications filed. 
Figure 10. USPTO applications by region of origin in 2006

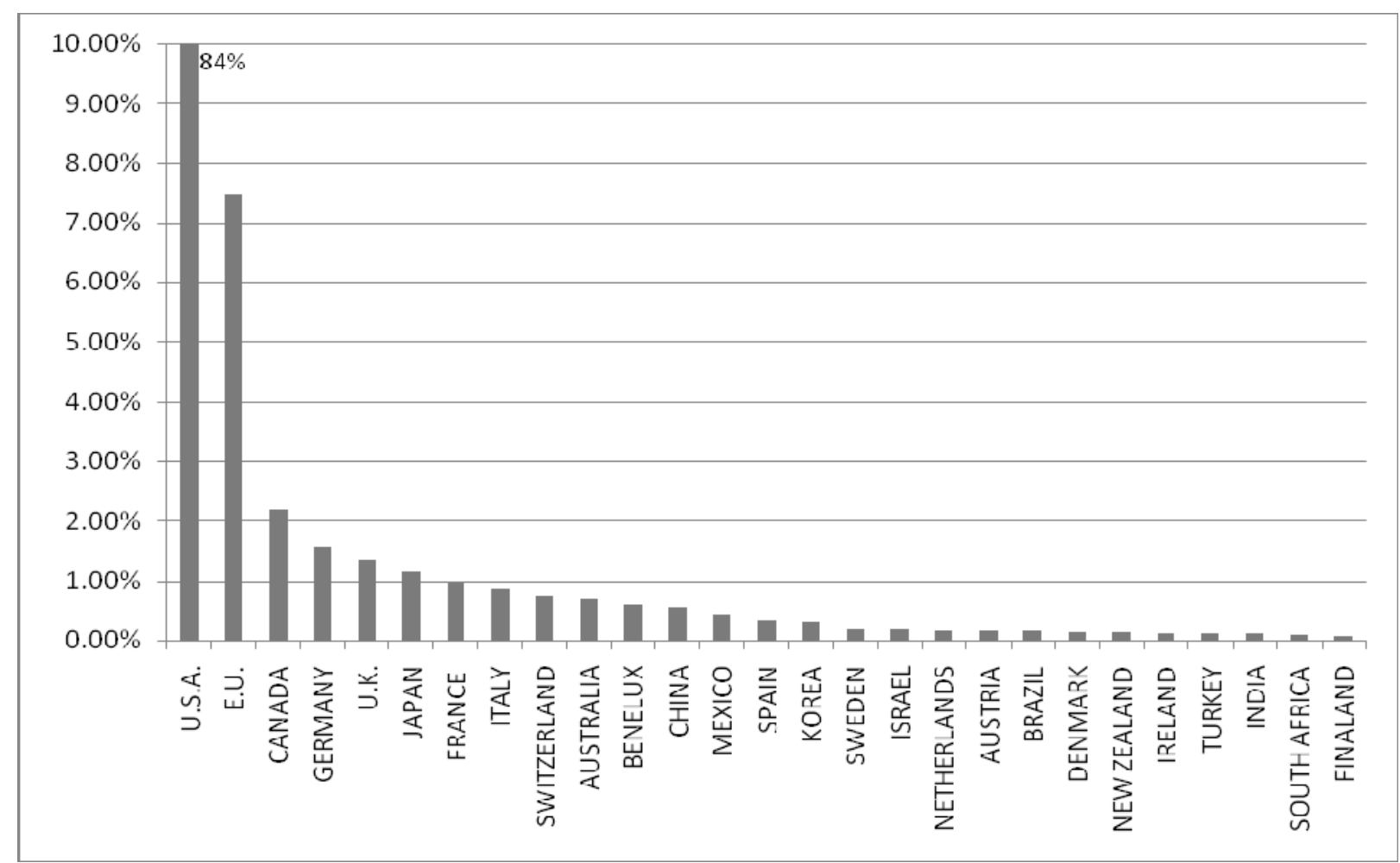

Source: WIPO Statistical Database.

Figure 11. JPO applications by region of origin in 2006

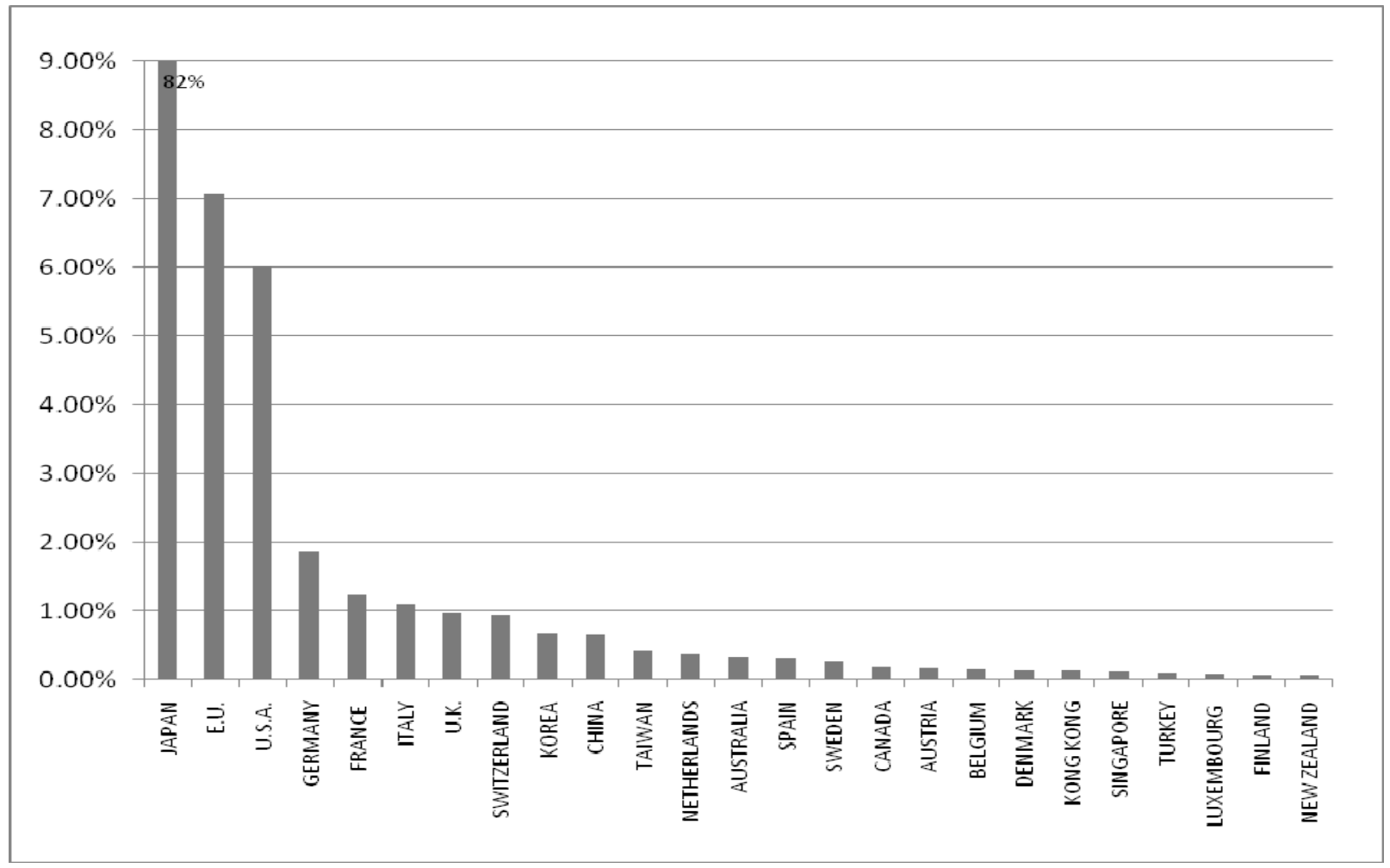

Source: JPO Annual Report 2006-2007. 
The domestic bias is slightly smaller in the OHIM, as CTM are international trademarks, and are then less related to the local market. E.U. residents make $67 \%$ of applications at OHIM, against more than $80 \%$ for US residents at USPTO and Japanese residents at JPO. The home bias is still non-negligible. CTM data might then enable comparisons to be made between various European countries, but not between non-European countries and European countries.

Considering the international data from WIPO does not solve this problem. Indeed some countries, notably the United States, have not been part of the Madrid system for very long. Moreover, the propensity to use the international procedure varies across countries.

Hence in order to make relevant international comparisons of trademark data, one should combine the data of various offices.

A first possibility is, as for patents, to build families of trademark applications according to the priority date of the applications, and to work at the level of "triadic trademarks", that is trademarks registered at the OHIM, the USPTO and the JPO. Yet if we use this method we lose some information, as many trademarks are strongly associated to a specific national market and have no international vocation, especially since trademarks are strongly related to language and other cultural aspects. Moreover, a same product can be protected by different unrelated trademarks across countries (e.g. Danone known as Dannon in the United States).

Another possibility would be to build indicators based on the data of one trademark office, replacing the number of domestic applications by an estimation based on the data of other offices, according to the following method. (in line):

Table 2 represents the number of applications in 2006 in the three major offices (in column) by origin

Table 2. Applications in the 3 major offices by origin

\begin{tabular}{|c|c|c|c|c|}
\hline & \multicolumn{3}{|c|}{ Trademark Office } \\
\hline & & USPTO & OHIM & JPO \\
\hline \multirow{3}{*}{ 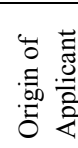 } & US & 233312 & 12699 & 8160 \\
\hline & Europea & 19467 & 53417 & 9598 \\
\hline & Japanese & 3158 & 1735 & 111754 \\
\hline
\end{tabular}

Source: OHIM and JPO annual reports, year 2006-2007, WIPO statistical database for USPTO figures.

For each office, it is possible to compare the numbers of applications from foreign countries between them, but they cannot be compared with the number of applications from residents of the country (in grey), because of the home bias.

It is however possible to estimate a figure of the resident applications corrected from the domestic bias, based on the data from other offices. The number of resident applications in one office can be estimated by the proportion of applications of the country in the other offices times the size of the considered office, i.e. the total number of applications.

For example, if we consider the OHIM trademark applications, we can estimate a neutral number of resident applicants, based on the proportion of European applications in the foreign office, according to the following formula: 
- Based on the USPTO repartition of applications :

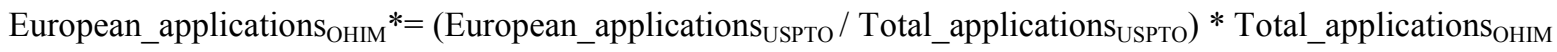

- Based on the JPO repartition:

European_applications $_{\mathrm{OHIM}}{ }^{* *}=\left(\right.$ European_applications $\mathrm{JPO}_{\mathrm{JP}} /$ Total_applications $\left._{\mathrm{JPO}}\right) *$ Total_applications $\mathrm{OHIM}_{\mathrm{OH}}$

This method is statistically relevant if the figures are robust, that is if the proportion of applications of the considered country relative to the other is stable across the two foreign offices: if the share of country A relative to country $\mathrm{B}$ among deposits of country $\mathrm{C}$ is close to the share of country A relative to country $\mathrm{C}$ in country B, divided by the share of country B relative to country C in country A. This condition is not verified with the figures of the matrix above. Indeed in terms of numbers of trademark applications we have the following relations:

- (1) in the JPO : American_applications $=0.85 *$ European_applications

- (2) in the USPTO : European_applications= $6.16 *$ Japanese_applications

- (3) in the OHIM : American_applications $=7.32 *$ Japanese_applications

If the relations were consistent with each other, the relation (3) would be:

- $\quad$ American_applications $=0.85 * 6.16$ Japanese_applications $=5.24 *$ Japanese_applications.

The Japanese applications are proportionally more numerous at the USPTO than at the OHIM. This is due to the fact that, as for patents, Japanese trademark applicants in Europe still tend to use more national procedures than the OHIM. We have then to take into account direct filings at national offices in Europe. If we compute the previous matrix replacing the numbers of applications at the OHIM by the addition of the applications at the OHIM and in the 25 national offices of Europe ${ }^{18}$, we obtain the following matrix:

\begin{tabular}{|c|c|c|c|c|}
\hline & \multicolumn{3}{|c|}{ Trademark Office } \\
\hline & & USPTO & $\begin{array}{c}\text { OHIM + European } \\
\text { national offices }\end{array}$ & JPO \\
\hline \multirow{3}{*}{ 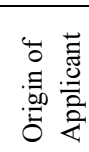 } & US & 233312 & 26021 & 8160 \\
\hline & European & 19467 & 534195 & 9598 \\
\hline & Japanese & 3158 & 5027 & 111754 \\
\hline
\end{tabular}

Sources: OHIM and JPO annual reports, year 2006-2007, WIPO statistical database for USPTO and EU national offices figures.

The relationship (3) then becomes:

- (4) in the OHIM + in European national offices : American_applications $=5.18 *$ Japanese_applications

18. There are 25 different national trademark offices in the European Union: one in each of the 27 countries, except Benelux which has one office for three countries. 
As relation (4) is consistent with relations (1) and (2), the figures are stable across offices when we consider both the OHIM and the European national offices. It is then possible to apply the above method to correct the home bias from the data of the various offices, which would make the figures concerning the geographical origin of the applications comparable between each other.

On the basis of the figures above, and without having applied further corrections, one would say that the level of trademark activity by American companies is slightly inferior to the level of European companies, both being more than five times higher than the level of Japanese companies. What these figures say exactly in terms of innovation has still to be analysed, but this exercise shows that at least the problem of international comparability of the data can be overcome.

\section{CONCLUSION}

Trademark data convey information on two key (overlapping) aspects of innovation which are not well covered by traditional indicators: marketing innovation and innovation in the service sectors. Certain empirical studies have shown the link between trademark counts and other indicators of innovation performance when they are available. For instance, trademark numbers at the firm level have been found positively correlated with innovation as reflected in responses to innovation surveys, with R\&D (for certain industries), with patents, and with the number of new product launches. This correlation is particularly high in knowledge-intensive services and in high-tech sectors like the pharmaceutical industry. A further advantage of trademarks as a source of data is their broad availability and relatively easy accessibility.

Yet, certain problems arise when using trademarks for measuring innovation: variations in legal systems across countries and over time, home bias in deposits, differences in behaviour of firms across countries or sectors. All those obstacles imply that some filters should be applied to trademark data when using them for compiling indicators of innovation.

These difficulties need first to be evaluated, which will be done by conducting further quantitative analysis of the data. Notably, trademark numbers will be correlated with various indicators of innovation and economic performance at the level of firms and industries, so as to find regularities and possible factors of correction. On the basis of this diagnosis, it is expected that technical solutions could be designed which would address these issues and will allow the compilation of meaningful indicators of marketing innovation and of innovation in the service sectors based on trademark data. 


\section{BIBLIOGRAPHY}

Aaker, D.A. (1991), Managing Brand Equity, The Free Press.

Akerlof, G. (1970), “The market for 'lemons': quality uncertainty and the market mechanism”, Quarterly Journal of Economics vol.84 pages 488-500.

Allegrezza, S. and A. Guard Rauchs (1999), "The Determinants of Trademark Deposits: an Econometric Investigation (A Case Study of the BENELUX)”, Economie Appliquée vol.52 (2), pages 51-68.

Baker, M. and S. Hart (2007), Product Strategy and Management, Prentice Hall: Financial Times, 2nd edition.

Baroncelli, E., C. Fink, and B.S. Javorcik (2005), “The Global Distribution of Trademarks: Some Stylised Facts", World Economy vol. 28, pages 765-78.

Cainelli, G., R. Evangelista, and M. Savona (2005), "Innovation and economic performance in services: a firm-level analysis", Cambridge Journal of Economics, vol. 30, pages 435-58.

Cohen, W., R. Nelson, and J. Walsh (2000), "Protecting their Intellectual Assets: Appropriability Conditions and why US Manufacturing Firms patent (or not)", NBER Working Paper no. 7552.

Davis, L. (Draft 2006), “How do trademarks affect firms' incentives to innovate?”, electronic version available at http://www.dime-eu.org/files/active/0/Davis.pdf.

Davis, S. (2002), "Brand asset management: how businesses can profit from the power of the brand", Journal of Consumer Marketing, Vol. 19 No.4, pp.351-8.

Economides, N. (1988), “The Economics of Trademarks", Trademark Reporter, pages 523-539.

Elliott, R. and L. Percy (2006), Strategic Brand Management, Oxford University Press.

Frame, S. and L. J. White (2002), “Empirical studies of financial innovation: lots of talk, little action?”, Federal Reserve Bank of Atlanta, Working Paper no.2002-12.

Greenhalgh, C. and M. Rogers (2007), "Trade Marks and Performance in UK Firms: evidence of Schumpeterian competition through innovation”, Economic Series Working Paper no. 300, University of Oxford, Department of Economics.

Griffiths, W.E., P.H. Jensen and E. Webster (2005), "The Effects on Firm Profits of the Stock of Intellectual Property Rights", Intellectual Property Research Institute of Australia Working Paper. no. $05 / 05$.

Kapferer, J.N. (1991), Les marques, capital de l'entreprise, Les Éditions d'Organisation. 
Landes, W.M. and R.A. Posner (1987), "The Economics of Trademark Law”, in The Economic Structure of Intellectual Property Law, Harvard University Press.

Lanham Act, or Trademark Act, (title 15, chapter 22 of the United States Code), 1946, last update in 2007, full text available at the Cornell Legal Information Institute, http://www.law.cornell.edu/uscode/html/uscode15/usc_sup_01_15 10 22.html.

Levin, R. C., A. K., Klevorick, R.R. Nelson and S.G. Winter (1987,) "Appropriating the Returns from Industrial Research and Development", Brookings Papers on Economic Activity, no.3, pages 783-820 (Yale survey).

Malmberg, C., (2005), “Trademark Statistics as Innovation Indicators? - A Micro Study”, CIRCLE Electronic Working Paper Series, 2005-17, CIRCLE (Centre for Innovation, Research and Competence in the Learning Economy), Lund University.

Maskus, K.E., S.M. Dougherty and A.P. Mertha (2004), "Intellectual Property Rights and Economic Development in China" in Fink, C. \& K.E. Maskus, Intellectual Property and Development: Lessons from Recent Economic Research, (Oxford: Oxford University Press and Washington DC: World Bank), pages 295-331.

Mendonça, S., T. S., Pereira and M. M. Godinho (2004), "Trademarks as an Indicator of Innovation and Industrial Change", Research Policy vol. 33(9), pages 1385-1404.

OECD (2005), "Proposed Guidelines for Collecting and Interpreting Innovation Data”, $3^{\text {rd }}$ edition, Oslo Manual, OECD, Paris.

Rogers, M. (1998), "The definition and measurement of innovation”, Melbourne Institute Working Paper no. $10 / 98$.

Schmoch, U. (2003), "Service Marks as Novel Innovation Indicator", in Research Evaluation, vol. 12 (2).

Seethamraju, C. (2003), “The value relevance of trademarks”, in J. Hand \& L. Baruch, Intangible assets: Values, measures and risks, Oxford University Press.

Swiners, J.L. (1979), "Bilan critique du rôle de la copy-stratégie dans la pratique publicitaire actuelle", IREP June -19.

Trott, P. (2005), Innovation Management and New Product Development, Prentice Hall: Financial Times, $3^{\text {rd }}$ edition.

WTO (1994), "Agreement on Trade-Related Aspects of Intellectual Property Rights", Annex 1C of the Marrakesh Agreement Establishing the World Trade Organization, full text available at http://www.wto.org/english/docs_e/legal_e/27-trips.pdf. 


\section{APPENDICES}

\section{Appendix 1. Short History of Trademark Systems}

The first kinds of trademark, as an identifying sign for a product, go back to antiquity. In the Roman Empire, bricks bore the name of their builder. But in terms of jurisdiction, the protection of TM by the law is originated in the UK, with the tort of Passing off, which is recognised in English Common Law relating to Goodwill since at least 1585 , and which prevents one person from misrepresenting his or her goods or services as being the goods and services of the plaintiff.

The first system of trademark registration was created in France in 1857, with the "Legislation Relating to Commercial Marks and Product Marks". Now it is used throughout the world. In the US, a comprehensive legislation relating to registration of trademarks was enacted as a federal law for the first time in 1870. In England, the Trade Mark Registration Act was enacted in 1875, based on the principle of prior use. In Turkey, a special law for the protection of trademarks, named the "Distinctive Signs Act", was adopted in the year 1871 during the Ottoman Emperorship; it introduced the registration of trademarks without examination. In Germany, a trademark protection law, which was based on the principle of no examination, was enacted in 1874 and was later modified with the introduction of the principle of mandatory examination. In Japan, the first trademark was registered in year 18 of the Meiji era (1885). It was a trademark for ointments and pills registered by Yuzen Hirai in Kyoto prefecture.

TM protection was incorporated in international law in 1891 by the Madrid Agreement, which gives member trademark owners the option of having their marks protected in several countries by simply filing one application. 
Appendix 2. Results of the CIS 4 Concerning the Use of Patents and Trademarks by Firms

Figure A2.1. Propensities to Use IPRs (Patents and Trademarks), All Core Industries

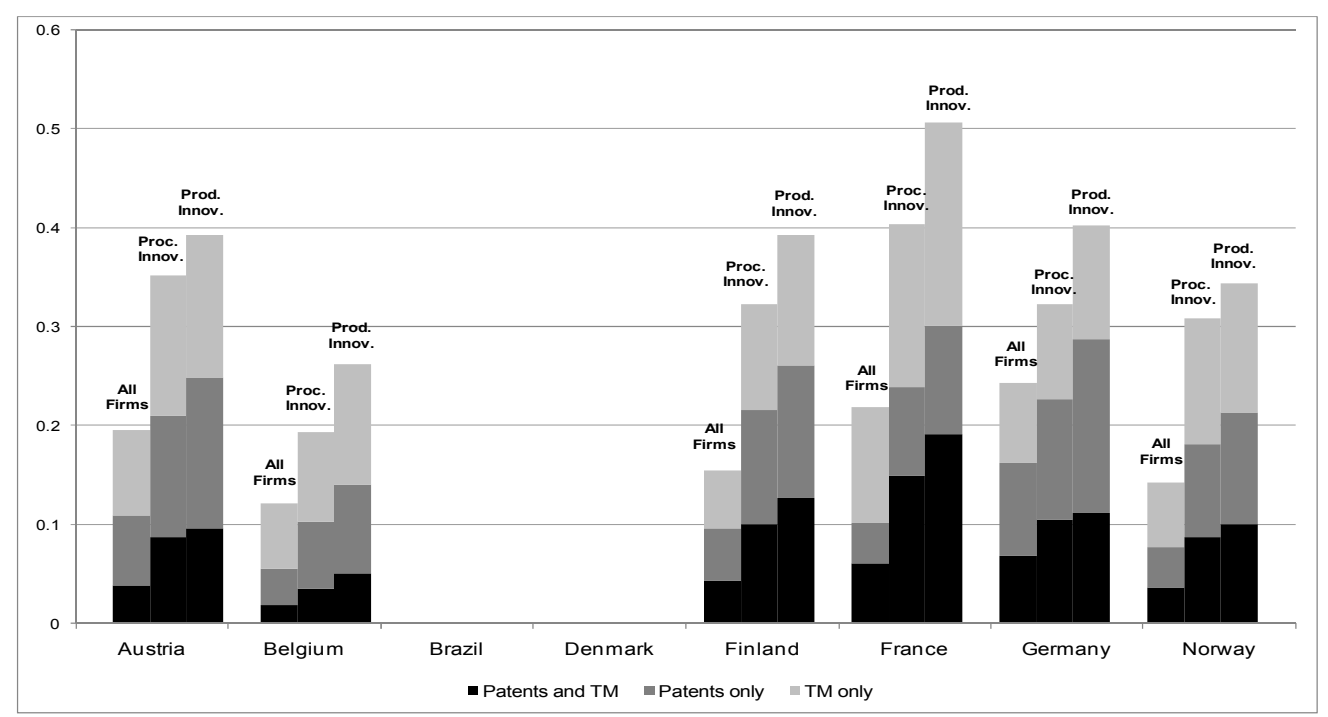

Source: Respective national innovation surveys, 2002/2004 (except for Austria, 1998/2000).

Figure A2.2. Propensities to Use IPRs (Patents and Trademarks), Manufacturing Industries

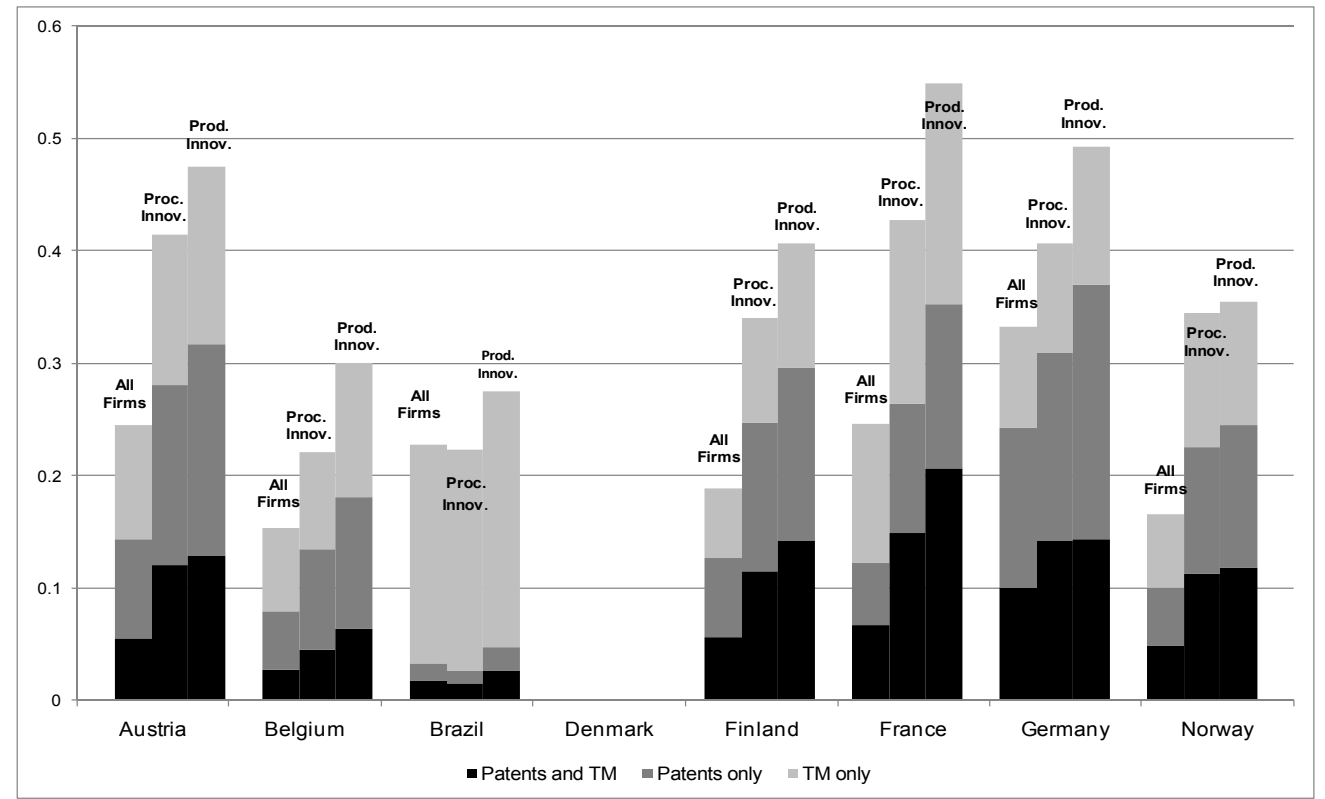

Source: Respective national innovation surveys, 2002/2004 (except for Austria, 1998/2000). 
Figure A2.3. Propensities to Use IPRs (Patents and Trademarks), Service Industries

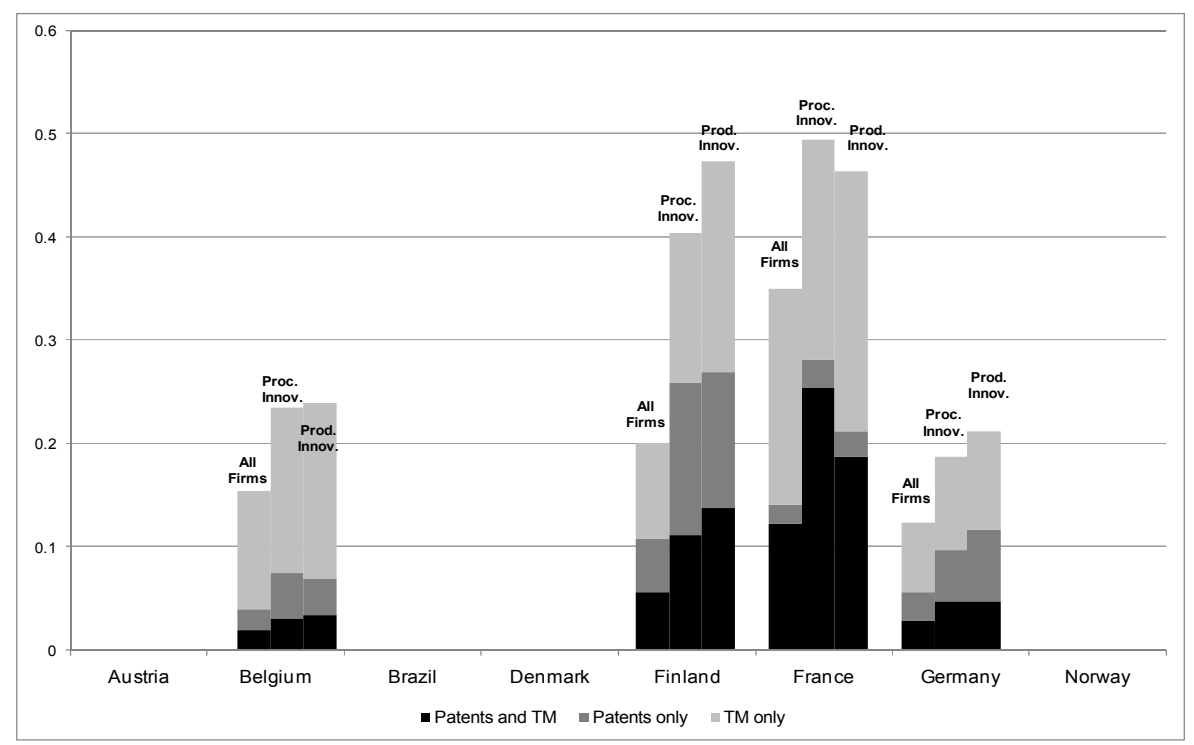

Source: Respective national innovation surveys, 2002/2004 (except for Austria, 1998/2000).

\section{Appendix 3. Conditions of Registrability of Trademarks}

Practically, any sign can be registered as a TM, as long as it is capable of being represented. There are yet various restrictions to registration.

- There are relative grounds of refusal, if the TM is similar to an already existing TM.

- There are also absolute grounds for the refusal of a TM registration: if the trademark refers to specific official emblems, if it has a scandalous connotation, or else if it has no distinctive character. Therefore marks that are merely descriptive of the product or service, or that are in common use, generally cannot be registered as trademarks, and remain in the public domain or use by anyone. For example the TM cannot simply be: the name of the product ("Chocolate"), the origin of the product ("fromage de Roquefort", "pruneaux d'Agen"), or signs only descriptive of the product or of its quality ("Salty" for saltine crackers). Moreover, certain marks can lose their property rights if they become generic ("genericized trademarks"). Indeed, if a court rules that a trademark has become "generic" through common use (such that the mark no longer performs the essential trademark function and the average consumer no longer considers that exclusive rights attach to it), the corresponding registration may also be ruled invalid. For example, the Bayer company's TM "Aspirin" has been ruled generic in the United States, so other companies may use that name for acetylsalicylic acid as well. 
DSTI/DOC(2009)6

\section{Appendix 4. International Treaties and Systems}

\section{(i) Treaties governing registration systems for obtaining protection}

The Madrid System for international registration of marks - 1891-1989

The Madrid system is the major international system for facilitating the registration of trademarks in multiple jurisdictions. It was established in 1891 and is ruled by the Madrid Agreement (1891) and the Madrid Protocol (1989). It is administered by the International Bureau of WIPO. It offers a TM owner the possibility of having his TM protected in several countries members of the Madrid Union, by simply filing one application in one jurisdiction with one set of fees. As of October 19, 2007, there were 57 contracting states to the Madrid Agreement and 81 to the Madrid Protocol. That does not include some major countries e.g. Canada. The US became party of the Madrid Protocol in 2003.

\section{The Community Trade Mark (CTM) System - 1994}

The CTM system, established in 1994, is intended to give proprietors the possibility of registering a trademark with validity throughout the European Community. The registration of a TM with the Office for Harmonization in the Internal Market (OHIM, European TM office) leads to a right which is effective throughout the European Community as a whole. CTM registration applies indivisibly across all European Community member states. An objection against a CTM application in any member state can defeat the entire application; if there is none, the CTM registration is enforceable in all member states. Nevertheless, the CTM system did not replace the national TM registration systems: they operate in parallel to each other.

\section{(ii) Treaties governing general standards of protection to be provided by States}

\section{The Paris Convention for the protection of Industrial Property - 1883}

The Paris Convention is the earliest treaty on the protection of TM and invention in general, dating back to 1883. It establishes the system of priority rights. Under priority rights, applicants have up to 6 months of grace period to extend the initial TM application (first filing of an application anywhere in the world, which generates the priority date) to other member countries and claim the earliest priority. The Paris convention also lays down a few common rules which all the contracting States must follow, concerning the registrability of TM, for example the interdiction to register a TM which might create confusion with a TM which is well-known in the State where the application is made.

\section{The Agreement on Trade-Related Aspects of Intellectual Property Rights (TRIPs) - 1994}

The Agreement on TRIPs, administered by the WTO, establishes legal compatibility between member jurisdictions by requiring the harmonisation of applicable laws concerning intellectual property. With respect to trademarks, the agreement defines what types of signs must be eligible for protection as a trademark and what the minimum rights conferred on their owners must be. The agreement states that marks that have become well-known in a particular country shall enjoy additional protection. In addition, the agreement lays down a number of obligations with regard to the use of trademarks, their term of protection, and their licensing or assignment. 


\section{(iii) Treaties governing general standards in the registration procedures}

The Trademark Law Treaty (TLT)-1994

The TLT is administered by the WIPO; its aim is to streamline national and regional TM registration procedures. It was adopted in Geneva on October 27, 1994 and entered into force on August 1, 1996. It establishes a system in which member jurisdictions agree to standardise procedural aspects of the TM registration process. For example, they have to restrain the indications required during the application for a TM (name, address of the applicant, indications about TM). They also have to apply the same length of the protection (ten years).

\section{(iv) Treaties governing international classification systems}

The Nice Agreement concerning the international classification of goods and services for the purpose of the registration of marks-1957

This agreement establishes a classification of goods and services for the purpose of registering TM (the Nice Classification). The TM offices of the contracting States must indicate, in the official documents and publications in connection with each registration, the numbers of the classes of the Classification to which the goods or services for which the mark is registered belong. The Classification consists of a list of classes - there are 34 classes for goods and 11 for services - and an alphabetical list of goods and services. 


\section{Appendix 5. National and Regional Specificities of the Various Trademark Systems}

On the whole the various trademark systems are relatively similar across countries. Comparing the various TM laws, they give roughly the same definition of a TM. The registration procedures, apart from the fees, are very similar in every country, except in the US where a use requirement is added to the common procedure. The registrability restrictions are also, apart from little details, very similar.

This homogeneity comes partly from the various international conventions and treaties concerning TM signed by a large number of countries. For European countries, the national TM laws generally correspond to the implementation of European directives, which explains the great similarity between European countries. Furthermore, the Paris Convention as well as the TRIPs agreement and the Trademark Law Treaty give guidelines on the procedures, counting methods and on the scope of the law, which implies a convergence between the various trademark laws. Most laws, notably the Chinese and the Hong Kong ones, were slightly modified to be consistent with the TRIPs.

However, if one pays attention to the details, some variations remain in the trademark legal systems, that may have a non-negligible impact on the data, and which must therefore be taken into account in the statistical analyses.

First, the question of registrability contains certain specificities according to offices.

First of all, a point of divergence is to be found in the kinds of signs that are registrable. Generally, any sign can be registered as a trademark as long as it can be represented graphically, including sounds that can be represented on a score, and smells that can be represented by their chemical formula. Yet this is sometimes challenged: in the CTM system as well as in the Chinese law, sounds and smells $(+$ single colours for CTM system) are not registrable as TM.

Besides, contrary to other countries' systems, the OHIM does not refuse registration on relative grounds. The office conducts searches of similar TM after an application is filed, but it is only informative. It is entirely up to individual entities to monitor and oppose other applications to register. The OHIM only prevents registration inherently unprotectable (for absolute grounds).

Moreover, the CTM system does not, contrary to the others, recognise acquired distinctiveness through use. All the jurisdictions refuse TM that are merely descriptive, without any distinctive character. Yet, most of the time, a clause is contained in the law which explains that TM that have acquired distinctiveness through use could be accepted, even if they are merely descriptive, except in the CTM system.

Lastly, as far as registrability is concerned, a specificity of the US law is the concept of incontestability, which arises after a registration is five years old. Once the registration is over five years old, it becomes incontestable if it is maintained through a showing of continuous use. It cannot be cancelled on grounds of prior use of a confusing similar mark or on grounds that the mark is merely descriptive. Yet, it can still be challenged on grounds of functionality, fraud, abandonment or that the mark is generic.

As far as the application procedure is concerned, it is nearly identical in every country. Yet, the US procedure includes a specific requirement of major importance: applications must be based on actual use or intent to use, and prove use before a registration will issue. When the application is based on bona fide intent to use, the applicant first receives a notice of allowance, and then has six months to prove the mark was used, that is the condition for the TM to be registered. 
Almost all the countries now apply the International classification of goods and services for the purpose of the registration of marks (Nice classification). One notable exception however is Canada, which has not joined the Nice Agreement.

As far as the length of protection is concerned, it is generally 10 years, renewable, although in Canada it is 15 years, and 7 years in Hong Kong.

Eventually, the status of unregistered TM is to be harmonised in the various laws. Unregistered TM can be protected by Common law as long as they are well-known, if the TM owner can prove that he effectively used the TM, and the use by another causes damages to his own business. Protection of well known TM was not initially included in every law, but it is a requirement of the Paris convention, also mentioned in the TRIPs. Hence it is now applied in almost every country. It is currently being introduced in the Chinese law, where unregistered TM were until now unprotected by law.

There are still further points of divergence between laws and especially accounting systems. Those variations must imperatively be taken into account in the analyses of trademark data. 


\section{Appendix 6. International Classification of Goods and Services for the Purposes of the Registration of Marks, established by the Nice Agreement (1957)}

\section{GOODS}

1. Chemicals used in industry, science and photography, as well as in agriculture, horticulture and forestry; unprocessed artificial resins; unprocessed plastics; manures; fire extinguishing compositions; tempering and soldering preparations; chemical substances for preserving foodstuffs; tanning substances; adhesives used in industry.

2. Paints, varnishes, lacquers; preservatives against rust and against deterioration of wood; colorants; mordants; raw natural resins; metals in foil and powder form for painters, decorators, printers and artists.

3. Bleaching preparations and other substances for laundry use; cleaning, polishing, scouring and abrasive reparations; soaps; perfumery, essential oils, cosmetics, hair lotions; dentifrices.

4. Industrial oils and greases; lubricants; dust absorbing, wetting and binding compositions; fuels (including motor spirit) and illuminants; candles, wicks.

5. Pharmaceutical, veterinary, and sanitary preparations; dietetic substances adapted for medical use, food for babies; plasters, materials for dressings; material for stopping teeth, dental wax; disinfectants; preparations for destroying vermin; fungicides, herbicides.

6. Common metals and their alloys; metal building materials; transportable buildings of metal; materials of metal for railway tracks; nonelectric cables and wires of common metal; ironmongery, small items of metal hardware; pipes and tubes of metal; safes; goods of common metal not included in other classes; ores.

7. Machines and machine tools; motors and engines (except for land vehicles); machine coupling and transmission components (except for land vehicles); agricultural implements other than handoperated; incubators for eggs.

8. Hand tools and implements (hand-operated); cutlery; side arms; razors.

9. Scientific, nautical, surveying, electric, photographic, cinematographic, optical, weighing, measuring, signalling, checking (supervision), life-saving and teaching apparatus and instruments; apparatus for recording, transmission or reproduction of sound or images; magnetic data carriers, recording discs; automatic vending machines and mechanisms for coin operated apparatus; cash registers, calculating machines, data processing equipment and computers; fire extinguishing apparatus.

10. Surgical, medical, dental, and veterinary apparatus and instruments, artificial limbs, eyes, and teeth; orthopedic articles; suture materials.

11. Apparatus for lighting, heating, steam generating, cooking, refrigerating, drying, ventilating, water supply, and sanitary purposes.

12. Vehicles; apparatus for locomotion by land, air, or water.

13. Firearms; ammunition and projectiles; explosives; fireworks. 
14. Precious metals and their alloys and goods in precious metals or coated therewith, not included in other classes; jewellery, precious stones; horological and chronometric instruments.

15. Musical instruments.

16. Paper, cardboard and goods made from these materials, not included in other classes; printed matter; bookbinding material; photographs; stationery; adhesives for stationery or household purposes; artists' materials; paint brushes; typewriters and office requisites (except furniture); instructional and teaching material (except apparatus); plastic materials for packaging (not included in other classes); playing cards; printers' type; printing blocks.

17. Rubber, gutta-percha, gum, asbestos, mica and goods made from these materials and not included in other classes; plastics in extruded form for use in manufacture; packing, stopping and insulating materials; flexible pipes, not of metal.

18. Leather and imitations of leather, and goods made of these materials and not included in other classes; animal skins, hides; trunks and travelling bags; umbrellas, parasols and walking sticks; whips, harness and saddlery.

19. Building materials (non-metallic); non metallic rigid pipes for building; asphalt, pitch and bitumen; non metallic transportable buildings; monuments, not of metal.

20. Furniture, mirrors, picture frames; goods (not included in other classes) of wood, cork, reed, cane, wicker, horn, bone, ivory, whalebone, shell, amber, mother-of-pearl, meerschaum and substitutes for all these materials, or of plastics.

21. Household or kitchen utensils and containers (not of precious metal or coated therewith); combs and sponges; brushes (except paint brushes); brush making materials; articles for cleaning purposes; steel wool; unworked or semi worked glass (except glass used in building); glassware, porcelain and earthenware not included in other classes.

22. Ropes, string, nets, tents, awnings, tarpaulins, sails, sacks and bags (not included in other classes); padding and stuffing materials (except of rubber or plastics); raw fibrous textile materials.

23. Yarns and threads, for textile use.

24. Textiles and textile goods, not included in other classes; beds and table covers.

25. Clothing, footwear, headgear.

26. Lace and embroidery, ribbons and braid; buttons, hooks and eyes, pins and needles; artificial flowers.

27. Carpets, rugs, mats and matting, linoleum and other materials for covering existing floors; wall hangings (non textile).

28. Games and playthings; gymnastic and sporting articles not included in other classes; decorations for Christmas trees.

29. Meat, fish, poultry and game; meat extracts; preserved, dried and cooked fruits and vegetables; jellies, jams, fruit sauces; eggs, milk and milk products; edible oils and fats. 
30. Coffee, tea, cocoa, sugar, rice, tapioca, sago, artificial coffee; flour and preparations made from cereals, bread, pastry and confectionery, ices; honey, treacle; yeast, baking powder; salt, mustard; vinegar, sauces (condiments); spices; ice.

31. Agricultural, horticultural and forestry products and grains not included in other classes; live animals; fresh fruits and vegetables; seeds, natural plants and flowers; foodstuffs for animals; malt.

32. Beers; mineral and aerated waters and other non alcoholic drinks; fruit drinks and fruit juices; syrups and other preparations for making beverages.

33. Alcoholic beverages (except beers).

34. Tobacco; smokers' articles; matches.

\section{SERVICES}

35. Advertising; business management; business administration; office functions.

36. Insurance; financial affairs; monetary affairs; real estate affairs.

37. Building construction; repair; installation services.

38. Telecommunications.

39. Transport; packaging and storage of goods; travel arrangement.

40. Treatment of materials.

41. Education; providing of training; entertainment; sporting and cultural activities.

42. Scientific and technological services and research and design relating thereto; industrial analysis and research services; design and development of computer hardware and software; legal services.

43. Services for providing food and drink; temporary accommodations.

44. Medical services; veterinary services; hygienic and beauty care for human beings or animals; agriculture, horticulture and forestry services.

45. Personal and social services rendered by others to meet the needs of individuals; security services for the protection of property and individuals. 